\title{
Currency Regimes, Volatility Risks, and Carry Trades: The Option Value of Government Currency Intervention in Emerging Markets
}

\author{
Wenliang Guo ${ }^{1}$
}

\begin{abstract}
This study investigates the relationship between cross-sectional carry trade returns and global foreign exchange volatility risk. During periods of high volatility innovations, the average carry trade returns on emerging markets are higher than that of all countries or developed economies. Furthermore, the average returns on managed-float and fixed-rate carry trades are significantly higher than that of freefloat carry trade. Government currency intervention in emerging markets can explain these differences. There is an option value in government currency intervention, which can be calculated using an American currency option model with stochastic strikes. This result has policy implications.
\end{abstract}

JEL classification numbers: F31, G12, G18

Keywords: Carry Trade, Emerging Markets, Currency Regime, Currency Intervention, Currency Option.

\section{Introduction}

This study investigates the risk return profile of a popular trading strategy called carry trade, which goes long in baskets of currencies with high interest rates and short in baskets of currencies with low interest rates. Empirically, I follow much of the recent literature, including the study by Menkhoff, Sarno, Schmeling, and Schrimpf (2012), but introduce many more currency pairs, including 40 emerging markets, all of which are US dollar (USD) denominated. Using almost the same empirical methods, my analysis yields different results. In periods of high volatility

1 PBC School of Finance, Tsinghua University, 43 Chengfu Road, Beijing 100083, China.

Article Info: Received: December 8, 2019. Accepted: December 23, 2019.

Published online: April 1, 2020 
innovations, the average carry trade returns on emerging markets are higher than that of all countries or developed economies. Furthermore, the average returns on managed-float and fixed-rate carry trades are significantly higher than that on freefloat carry trade. The results for developed economies and free-float emerging markets are similar to that of Menkhoff et al. (2012).

I sort the currencies into 5 portfolios (Portfolios 1 to 5) according to their forward discounts at the end of each month, a method similar to Menkhoff et al. (2012). Lustig, Roussanov, and Verdelhan (2011) show that sorting by forward discount is almost equivalent to sorting by the country's interest rate differentials against the US money market rate. Here, Portfolio 5 contains the highest interest rate quintile while Portfolio 1 contains the lowest interest rate quintile. By going long on Portfolio 5 the (highest interest rate quintile) and shorting portfolio 1 (the lowest interest rate quintile), I form a carry trade portfolio (Portfolio H/L). The carry trade portfolio of emerging markets offers an average of over 8 percent annual return, even considering the market turmoil during the global financial crisis and accounting for transaction costs.

I also construct the global foreign exchange volatility factor (VOL) proposed by Menkhoff et al. (2012). Then, I take the AR(1) regression of global foreign exchange volatility. The residue is called innovation in global foreign exchange volatility (innovation to VOL or volatility innovations). Similar to Menkhoff's empirical methods, I sort carry trade portfolios into 4 groups by the sample's volatility innovations. Group Low contains the months of carry trade returns with the lowest volatility innovations, while Group High contains the months of carry trade returns with the highest volatility innovations. For developed economies, the average carry trade return for Group High (or equivalently, during periods of high volatility innovations in the sample) is negative. This conforms to Menkhoff's finding. However, if I include emerging markets, the result changes. The average carry trade return on emerging markets becomes much higher in periods of high volatility innovations in the sample. Even if I control the volatility innovations to G10 ${ }^{2}$ volatility innovations, the average carry trade return on emerging markets is still much higher than that of all countries or developed economies in periods of high G10 volatility innovations.

Furthermore, I select 28 emerging markets with easily classified exchange rate regimes in the sample period and divide them into three groups: 8 free-float, 10 managed-float, and 10 fixed-rate regimes based on the IMF's de facto classification criteria. To balance the weighting effects of the portfolio, I combine each group separately with G10 countries/economies. Similar to the previous method, I sort the carry trade portfolios by forward discount and then by their volatility innovations (or G10 volatility innovations). The empirical results become even more interesting. For G10 and the 8 free-float emerging markets (free-float carry trade), the average carry trade return is negative (highly significant) during periods of high volatility

2 The G10 countries/economies are the Euro area, Japan, the United Kingdom, Australia, Canada, Switzerland, Sweden, New Zealand, Norway, and Denmark. All exchange rates are against USD. 
innovations, similar to the result in developed economies. However, for G10 and the 10 managed-float emerging markets (managed-float carry trade), the average carry trade return is close to zero (insignificant), much higher than that for free-float carry trade. A similar result holds for G10 and the 10 fixed-rate emerging markets (fixed-rate carry trade), whose average carry trade return is also close to zero (insignificant) during periods of high volatility innovations.

This finding is interesting. According to the Bank for International Settlements Triennial Central Bank Survey: Foreign Exchange Turnover in April 2016, the currency trading volume of emerging markets comprises over 18 percent (out of 200 percent) of global FX trading volume. This is significant trading volume, but prior studies pay only limited attention to emerging markets. This study attempts to fill this gap and tries to explain the return differences between free-float and managed-float carry trades during periods of high volatility innovations.

Government currency intervention in emerging markets can explain the return differences. Intuitively, in periods of high volatility innovations, government currency intervention prevents managed-float/fixed-rate investment currencies from depreciating too much and funding currencies (if they are also managed-float or fixed-rate) from appreciating too much. Therefore, the intervention improves the carry trade returns. Empirically, in months of high G10 volatility innovations, the investment currencies of the free-float carry trade depreciates around 24 percent on average on an annual basis, while the investment currencies of the managed-float carry trade depreciates by only about 16 percent on average on an annual basis. The returns on the funding currencies between different exchange rate regimes are close to each other. Currency intervention mostly affects the returns on investment currencies.

I also present an indirect evidence that government currency intervention causes the return difference between free-float and managed-float (or fixed-rate) carry trades. I use countries in the monitoring lists in Macroeconomic and Foreign Exchange Policies of Major Trading Partners of the United States from 2016 to 2019. The reports were prepared semi-annually by U.S. Department of Treasury to U.S. Congress. Although the countries are limited in number, the monitoring list specifically identifies the authorities that use FX intervention. I combine them with G10 countries and re-do the analysis. The result shows that the carry trade returns of G10 and the monitoring list significantly outperform that of free-float carry trade in periods of high volatility innovations, but remain ambiguous compared to managed-float or fixed-rate carry trade, in line with previous analysis.

There is an option value in government currency intervention, which we can think of as a combination of put and call options. When local currency is depreciating against the USD, local governments or central banks intervene to prop up its exchange rate by selling USD to meet excess market demand. The exchange rate (which we can consider a strike price) is higher than what it would be (which we can consider as the hypothetical underlying exchange rate) if the government would just let it free float. From the perspective of investors with excess demand for USD, the local government essentially gives them a portfolio of currency put options with 
different strikes for free. These put options compensate them for part of the loss if they were in a free-float regime. When the local currency is appreciating against the USD, local governments or central banks intervene to prevent the local exchange rate from rising too much by buying the excess USD in the market. The actual exchange rate is lower than what it would be if the government would just let it free float. We can also consider this as the strike price, while we can view the hypothetical free-float exchange rate as the underlying exchange rate. Similar to a put option, from the perspective of investors with excess demand for local currencies, they allow the government to issue local currencies to exchange for USD, which essentially means that they gives the government a portfolio of currency call options with different strikes for free. Taken together, we can see currency intervention as a portfolio of long puts and short calls with different strike prices. There is an interesting trade-off faced by investors in the presence of government intervention: carry trade investing in emerging (managed) currencies lose less when volatility innovation is high, but also gain less when volatility innovation is low. The net effect on the carry trade is lower volatility but the effect on the mean is ambiguous. It depends on the relative valuation of long put vs short call options imbedded in government intervention.

I show that the strike prices of the embedded options in government intervention, together with all currency reserves and the amount of USD that the local government is willing to use to intervene at each price, is equivalent to a stochastic process with some probability measure. When the local currency is depreciating, put options are in the money and valuable, but call options are worthless because they are out of the money. In this case, I propose an American currency put option model with stochastic strikes and use Monte Carlo methods to calculate the embedded put option value in government currency intervention. However, when the local currency is appreciating, call options are in the money and valuable, but put options are out of the money and worthless. I also propose an American currency call option model with stochastic strikes and use Monte Carlo methods to calculate the embedded call option value in government currency intervention. The 50\% percentile of both option values are very close to the return differences between managed-float and free-float carry trade portfolios during periods of high or low volatility innovations.

This model also has some interesting policy implications. First, the option value in government currency intervention can be an indicator and measure of potential government currency intervention. Second, for a major economy, gradual reform to its currency regime is usually more preferable than a sudden change. Third, the appropriate timing for a major economy, such as China, to change smoothly from managed-float to free-float is when its currency becomes a funding currency. Fourth, China's exchange rate reform on Aug. $11^{\text {th }}, 2015$ actually changed the probability distribution of the strike prices and increased the value of the put option in government currency intervention. The People's Bank of China inevitably had to spend more currency reserves to defend the RMB.

The paper proceeds as follows: Section 2 discusses my study in the context of the 
existing literature. Section 3 describes the data and the currency portfolios. Section 4 reports the empirical results and regression analysis. Section 5 presents the model of option value in government currency intervention and calculates the option prices. Section 6 discusses the policy implications and future research development. Section 7 concludes.

\section{Related Literature}

The study relates to three areas of the literature, including carry trade, currency intervention, and option pricing.

First, we can divide the existing literature on carry trade into two sub-categories based on two broad questions: Does carry trade exist? What affects or predicts carry trade returns?

As to the existence of carry trade, Hansen and Hodrick (1980) and Fama (1984) document violations of uncovered interest rate parity (UIP). Heath, Galati, and McGuire (2007) find evidence supporting of carry trade and point out that a sudden reversal in carry trade will affect the stability of financial markets. Burnside, Eichenbaum, and Rebelo (2008) show a significant return on carry trade, comparable to stock returns in the long run. Ranaldo and Söderlind (2010) document safe haven properties of the Swiss Franc and Japanese Yen. Burnside, Han, Hirshleifer, and Wang (2011) offer an explanation for the forward premium puzzle based on investor overconfidence while $\mathrm{Yu}$ (2013) proposes a sentimentbased model to explain the forward premium puzzle. Gilmore and Hayashi (2011) argue that picking emerging market currencies with high forward premium increases carry trade return substantially. They also find that the transaction costs of emerging market currencies are less than one-fifth of what was previously assumed.

As to the factors affecting carry trade return, Bansal and Dahlquist (2000) point out that the interest rate is just one of the factors that affect carry trade return. Lustig and Verdelhan (2007) argue that aggregate consumption growth risk explains variations in carry trade return. Brunnermeier, Nagel, and Pedersen (2008) state that the profitability of carry trade relates to global risk aversion. Jordà and Taylor (2012), and Nozaki (2010) design separate carry trade strategies. Works by Lustig et al. (2011) and Lustig, Roussanov, and Verdelhan (2014) relate the cross-sectional evidence of carry trade strategies to slope factors and aggregate risks. Burnside, Eichenbaum, Kleshchelski, and Rebelo (2011) and Farhi, Fraiberger, Gabaix, Ranciere, and Verdelhan (2009) argue that the Peso problem or disaster risk can account for part of the carry trade risk premium. Jurek (2014) counter-argues that high returns to carry trade are not due to the Peso problem. Bakshi and Panayotov (2013) find that a liquidity measure predicts carry trade returns. Chernov, Graveline, and Zviadadze (2018) point out that jump risk in currency variance may be priced, but is unrelated to the interest rate or macroeconomic news. Sarno, Schneider, and Wagner (2012) discuss the properties of foreign exchange risk premiums. Londono and Zhou (2017) provide empirical evidence that foreign exchange risk premiums 
and variance risk premiums can explain the forward premium puzzle. Lee and Wang (2019) argue that currencies that are more sensitive to negative jumps offers significantly higher returns.

A relevant paper by Burnside (2015) studies the carry trade in emerging markets. $\mathrm{He}$ focuses on UIP in emerging markets and finds that there are less regressionbased evidence but the carry trade is still profitable. He also shows that the commonly-used risk factors cannot explain the returns to emerging market currencies, but stops short of explanation. My research differs that I focuses on the carry trade in emerging markets with far more countries involved and with respect to volatility innovations. My paper also provide an explanation that government currency intervention causes variations in carry trade return on emerging markets. Accominotti, Cen, Chambers, and Marsh (2017) touches on the topic on currency regimes and carry trade. The authors document that over the last century, outsized carry returns only occur in floating regimes and are zero in fixed regimes. Their data covers only 19 developed economies for almost a hundred years for countries that shifted from fixed-rate to floating regimes. My data, however, covers 62 economies, including 40 emerging markets from 2000 to 2017. I compare the countries with different exchange rate regimes for the same time period, which yields different results.

My work is closely related to that of Menkhoff et al. (2012), who find that global foreign exchange volatility risk is priced in currency markets. My study extends their findings by introducing more emerging markets, most of which are managedfloating, or fixed-rate regimes.

Second, on currency intervention, Neely (2000), Mandeng (2003), and Keefe and Rengifo (2014) discuss methods of currency intervention including spot, forward, swap, and direct issuance of currency options. Kriljenko (2003) shows empirically that 82 percent of currency intervention occurs through spot transactions in emerging markets and other developing countries. Cassino and Lewis (2012) examine the profitability of central bank currency interventions. Sarno and Taylor (2001) and Disyatat and Galati (2007) study the effects and efficacy of currency intervention in emerging markets. Melvin, Menkhoff, and Schmeling (2009) show empirically that intervention has stabilizing effects conditional on large currency reserves and the existence of capital controls. Fry-McKibbin and Wanaguru (2013) report on a case study of currency intervention in Sri Lanka and find that this emerging market's central bank intervened and accumulated foreign exchange reserves (FX reserves) in low volatility periods, while mitigating excess volatility in high volatility periods.

Third, for currency options, my work relates mostly to that of Longstaff and Schwartz (2001), who develop a Monte Carlo method to calculate American options. 


\section{Data and Currency Portfolios}

This section describes the data used in the empirical analysis, carry trade portfolio construction, proxy for global foreign exchange volatility risk, and descriptive statistics.

\subsection{Data on spot and forward rates}

I start with daily closing spot and one-month forward rates versus USD and transform them into a monthly series. The spot and forward rates include bid, ask, and mid prices. The sample period is from January 1, 2000 to March 31, 2017. I collected these data from Reuters via Datastream. The main dataset has 62 economies, including 22 developed economies and 40 emerging markets and developing countries (based on the IMF's classification in World Economic Outlook: Too Slow for Too Long in 2016). For simplicity and to prevent ambiguity, I refer to the emerging markets and developing countries simply as emerging markets. The countries/economies in the data set are: Argentina, Australia, Botswana, Brazil, Bulgaria, Canada, Chile, China, Colombia, Croatia, Czechia, Denmark, Egypt, Estonia, the Euro area, Ghana, Hong Kong, Hungary, Iceland, India, Indonesia, Israel, Japan, Jordan, Kazakhstan, Kenya, Kuwait, Latvia, Lithuania, Malaysia, Mexico, Morocco, New Zealand, Norway, Oman, Pakistan, Peru, the Philippines, Poland, Qatar, Romania, Russia, Saudi Arabia, Serbia, Singapore, Slovakia, Slovenia, South Africa, South Korea, Sri Lanka, Sweden, Switzerland, Taiwan, Thailand, Tunisia, Turkey, Ukraine, Uganda, the United Arab Emirates, the United Kingdom, Vietnam, and Zambia. The one-month forward rates for Argentina, Chile, Colombia, Egypt, Peru, and Malaysia are not available, so I use the one-month nondeliverable forward rates (NDF) as substitutes. I also exclude two anomaly periods when the forward rates provided by Reuters (Datastream) do not change: Turkey from 02/19/2001 to 12/25/2001 and Indonesia from 02/16/2001 to 06/01/2007.

According to the IMF's 2016 World Economic Outlook: Too Slow for Too Long, the 22 developed countries/economies are: Australia, Canada, Czechia, Denmark, Estonia, the Euro area, Hong Kong, Iceland, Israel, Japan, Latvia, Lithuania, New Zealand, Norway, Singapore, Slovakia, Slovenia, South Korea, Sweden, Switzerland, Taiwan, and the United Kingdom. The remaining 40 emerging markets are: India, Malaysia, the Philippines, Poland, South Africa, Thailand, Argentina, Botswana, Brazil, Bulgaria, Chile, China, Colombia, Croatia, Egypt, Ghana, Hungary, Indonesia, Jordan, Kazakhstan, Kenya, Kuwait, Mexico, Morocco, Romania, Turkey, Oman, Pakistan, Peru, Qatar, Russia, Saudi Arabia, Serbia, Sri Lanka, Tunisia, the United Arab Emirates, Ukraine, Uganda, Vietnam, and Zambia.

\subsection{Portfolio construction}

Similar to Menkhoff et al. (2012), I allocate the currencies to five portfolios based on their forward discounts $f d_{t}^{k}=f_{t}^{k}-s_{t}^{k}$ at the end of month $t$ ( $k$ represents the currency). As Lustig et al. (2011) point out, sorting by the forward discount is equivalent to sorting by interest rate differentials. Since the base currency is USD, 
Portfolio 1 has the lowest interest rate differentials against the USD, while Portfolio 5 has the highest interest rate differentials against the USD. I rebalance the portfolios at the end of the month. I add currencies with missing data to the portfolio as the data become available and drop it from the portfolio if the data are not available.

For each currency $k$, the log monthly excess return for holding it is

$$
r x_{t+1}^{k} \equiv i_{t}^{k}-\left(i_{t}+\Delta s_{t+1}^{k}\right) \approx f_{t}^{k}-s_{t+1}^{k}
$$

where $f_{t}^{k}$ is the log forward rate of currency $k$ at the end of month $t . s_{t+1}^{k}$ is the $\log$ spot rate of currency $k$ at the end of month $t+1$. Lustig et al. (2011) prove that the latter part of equation (1) approximately holds.

For each portfolio $i$, I take the arithmetic average of $r x_{t+1}^{k}$ over $k$ in the portfolio to get the $\log$ currency excess return (gross return) $r x_{i, t+1}$ for the portfolio. Since there are five portfolios at the end of each month, there are five values for $r x_{i, t+1}$. For transaction costs, since Reuters (Datastream) provides bid/ask/mid prices for each currency, I mostly follow Menkhoff et al. (2012) method to compute the bidask spread (BAS) adjusted returns for each currency. In my setup, whenever a currency enters or exits the portfolio, either by a long or short position, I deduct its transaction cost by adjusting for bid-ask spread. This can be done for three scenarios. First Scenario: A currency enters the portfolio at the beginning of month $t$ (for continuity, I use the price at the close of month $t-1$ as a substitute) and exits the portfolio at the end of the month $t$. The excess return is $r x_{t}^{\text {long }}=f_{t-1}^{b i d}-s_{t}^{\text {ask }}$ for a long position and $r x_{t}^{\text {short }}=-f_{t-1}^{a s k}+s_{t}^{b i d}$ for a short position.

Second Scenario: A currency enters a portfolio at the beginning of month $t$, but stays in the portfolio at the end of the month. Its excess return is $r x_{t}^{\text {long }}=f_{t-1}^{\text {bid }}-s_{t}^{\text {mid }}$ for a long position and $r x_{t}^{\text {short }}=-f_{t-1}^{a s k}+s_{t}^{\text {mid }}$ for a short position.

Third Scenario: A currency exits a portfolio at the end of month $t$, but was already in the currency portfolio before month $t$. Its excess return is $r x_{t}^{\text {long }}=f_{t-1}^{\text {mid }}-s_{t}^{\text {ask }}$ for a long position and $r x_{t}^{\text {short }}=-f_{t-1}^{\text {mid }}+s_{t}^{\text {bid }}$ for a short position.

For the five currency portfolios, I adjust Portfolio 1 (the funding currencies) for transaction costs in the short position and Portfolios 2 to 5 (the investment currencies) in the long position. For simplicity and hereafter, the portfolios already exist at the beginning of the period and continue to exist the end of the period.

The return difference between Portfolio 5 and Portfolio 1 is the H/L carry trade portfolio by borrowing money in the lowest interest rate currencies and investing in the highest interest rate currencies. I refer to the average return on all five currency portfolios as the DOL portfolio. Lustig et al. (2011) call this portfolio the "Dollar risk factor," which is the average returns on a strategy that borrows in USD and invests in global money markets outside the US. 


\subsection{Descriptive statistics for the portfolios}

Table 1 summarizes the descriptive statistics for Portfolios 1 to 5, the average return portfolio (DOL), and the H/L carry trade portfolio of all countries, developed economies, and emerging markets.

Table 1 reports the mean returns (annualized), median returns (annualized), standard deviations (annualized), skewness, and kurtosis of the currency portfolios sorted monthly by forward discounts at the end of the previous month. Maximum returns, minimum returns, and Sharpe Ratios are also reported. Parts A, B, and C report the results for all countries, developed economies, and emerging markets, respectively. For each part, Portfolio 1 contains the 20 percent of the currencies with the lowest forward discounts, while Portfolio 5 contains the 20 percent of the currencies with the highest forward discounts. The base currency is USD. All portfolio returns are in excess USD returns. Returns on Portfolio 1 are adjusted for transaction costs in short positions and the returns on Portfolios 2 to 5 are adjusted for transactions costs in long positions. Column DOL is the average return on all five portfolios (the dollar risk factor). Column $\mathrm{H} / \mathrm{L}$ is the return on Portfolio 5 minus Portfolio 1, which is the carry trade portfolio. The spot spread and forward spread are the end-of-month average bid-ask spot and forward spreads for each portfolio in basis points. The sample period is from March 2000 to February 2017.

Table 1: Descriptive Statistics

\begin{tabular}{|l|c|c|c|c|c|c|c|}
\hline \multicolumn{7}{|c|}{ Part A: All Countries (with b-a) 2000-2017 } \\
\hline Portfolio & 1 & 2 & 3 & 4 & 5 & DOL & H/L \\
\hline Mean & $-1.62 \%$ & $-0.28 \%$ & $1.98 \%$ & $3.58 \%$ & $6.78 \%$ & $1.95 \%$ & $8.40 \%$ \\
\hline Median & $-0.86 \%$ & $0.72 \%$ & $3.25 \%$ & $3.24 \%$ & $7.62 \%$ & $2.67 \%$ & $8.33 \%$ \\
\hline Maximum & $4.64 \%$ & $4.78 \%$ & $5.46 \%$ & $7.25 \%$ & $6.55 \%$ & $4.48 \%$ & $6.90 \%$ \\
\hline Minimum & $-4.56 \%$ & $-7.56 \%$ & $-10.62 \%$ & $-8.24 \%$ & $-9.48 \%$ & $-7.79 \%$ & $-5.62 \%$ \\
\hline Std. Dev. & $5.37 \%$ & $6.07 \%$ & $7.09 \%$ & $7.44 \%$ & $7.59 \%$ & $5.98 \%$ & $6.38 \%$ \\
\hline Skewness & -0.11 & -0.56 & -0.75 & -0.60 & -0.70 & -0.65 & -0.11 \\
\hline Kurtosis & 3.13 & 5.41 & 6.63 & 5.77 & 5.49 & 5.20 & 4.31 \\
\hline Sharpe Ratio & -0.30 & -0.05 & 0.28 & 0.48 & 0.89 & 0.33 & 1.32 \\
\hline Transaction Cost & $0.16 \%$ & $0.29 \%$ & $0.39 \%$ & $0.49 \%$ & $0.30 \%$ & $0.26 \%$ & $0.46 \%$ \\
\hline Spot Spread (bp) & 5.8 & 7.2 & 9.1 & 13.4 & 20.5 & & \\
\hline Forward Spread (bp) & 8.4 & 9.9 & 10.9 & 16.8 & 38.2 & & \\
\hline Observations & 204 & 204 & 204 & 204 & 204 & 204 & 204 \\
\hline \multicolumn{7}{|c|}{ Part B: Developed Economies (with b-a) 2000-2017 } & \\
\hline Portfolio & 1 & 2 & 3 & 4 & 5 & DOL & H/L \\
\hline Mean & $-1.84 \%$ & $-0.95 \%$ & $2.58 \%$ & $1.24 \%$ & $5.00 \%$ & $1.14 \%$ & $6.84 \%$ \\
\hline Median & $-2.21 \%$ & $-0.51 \%$ & $1.06 \%$ & $1.51 \%$ & $7.03 \%$ & $2.56 \%$ & $9.24 \%$ \\
\hline
\end{tabular}




\begin{tabular}{|l|c|c|c|c|c|c|c|}
\hline Maximum & $8.49 \%$ & $6.25 \%$ & $7.04 \%$ & $7.89 \%$ & $10.44 \%$ & $6.20 \%$ & $5.28 \%$ \\
\hline Minimum & $-4.90 \%$ & $-7.96 \%$ & $-9.28 \%$ & $-10.92 \%$ & $-13.01 \%$ & $-8.61 \%$ & $-11.50 \%$ \\
\hline Std. Dev. & $6.85 \%$ & $7.99 \%$ & $8.74 \%$ & $9.04 \%$ & $10.11 \%$ & $7.73 \%$ & $7.51 \%$ \\
\hline Skewness & 0.28 & -0.34 & -0.12 & -0.39 & -0.64 & -0.28 & -1.10 \\
\hline Kurtosis & 4.03 & 4.32 & 4.49 & 4.62 & 5.87 & 4.20 & 7.23 \\
\hline Sharpe Ratio & -0.27 & -0.12 & 0.30 & 0.14 & 0.50 & 0.15 & 0.91 \\
\hline Transaction Cost & $0.12 \%$ & $0.25 \%$ & $0.25 \%$ & $0.22 \%$ & $0.10 \%$ & $0.14 \%$ & $0.22 \%$ \\
\hline \multicolumn{7}{|c|}{ Table 1 Continued } \\
\hline Spot Spread (bp) & 6.0 & 5.7 & 5.9 & 6.8 & 10.7 & & \\
\hline Forward Spread (bp) & 8.5 & 6.2 & 6.9 & 8.6 & 8.4 & & \\
\hline Observations & 204 & 204 & 204 & 204 & 204 & 204 & 204 \\
\hline \multicolumn{7}{|c|}{ Part C: Emerging Markets (with b-a) } & $\mathbf{2 0 0 0 - 2 0 1 7}$ \\
\hline Portfolio & 1 & 2 & 3 & 4 & 5 & DOL & H/L \\
\hline Mean & $-0.67 \%$ & $0.87 \%$ & $-0.43 \%$ & $2.09 \%$ & $10.72 \%$ & $2.30 \%$ & $11.39 \%$ \\
\hline Median & $0.15 \%$ & $1.77 \%$ & $1.64 \%$ & $3.91 \%$ & $11.36 \%$ & $3.16 \%$ & $11.11 \%$ \\
\hline Maximum & $4.45 \%$ & $4.55 \%$ & $6.71 \%$ & $7.03 \%$ & $10.74 \%$ & $3.69 \%$ & $10.74 \%$ \\
\hline Minimum & $-2.96 \%$ & $-8.26 \%$ & $-8.11 \%$ & $-9.35 \%$ & $-10.01 \%$ & $-7.26 \%$ & $-7.18 \%$ \\
\hline Std. Dev. & $3.33 \%$ & $4.64 \%$ & $6.90 \%$ & $8.67 \%$ & $9.06 \%$ & $5.12 \%$ & $8.46 \%$ \\
\hline Skewness & -0.08 & -1.34 & -0.44 & -0.67 & 0.18 & -0.98 & 0.65 \\
\hline Kurtosis & 6.50 & 10.77 & 5.30 & 4.74 & 6.11 & 6.33 & 6.35 \\
\hline Sharpe Ratio & -0.20 & 0.19 & -0.06 & 0.24 & 1.18 & 0.45 & 1.35 \\
\hline Transaction Cost & $0.29 \%$ & $0.51 \%$ & $0.69 \%$ & $0.77 \%$ & $0.57 \%$ & $0.44 \%$ & $0.86 \%$ \\
\hline Spot Spread (bp) & 6.7 & 9.7 & 14.7 & 15.9 & 23.6 & & \\
\hline Forward Spread (bp) & 11.2 & 13.9 & 19.5 & 23.6 & 47.5 & & \\
\hline Observations & 204 & 204 & 204 & 204 & 204 & 204 & 204 \\
\hline
\end{tabular}

The sample contains 204 observations. As an equal weight strategy, the average returns increase monotonically from Portfolio 1 to Portfolio 5 and Portfolio H/L for all countries, but less monotonically for either developed economies alone or emerging markets alone. The average return on the five portfolios (Column DOL) is $1.95 \%$ per annum for all countries, indicating that US investors demand a positive premium for investing abroad. The Sharpe Ratio for Portfolio 5 for the developed economies is 0.5 , consistent with results in the previous literature, although the time period is different. Including emerging markets greatly increases the Sharpe Ratio; the Sharpe Ratio for Portfolio 5 for emerging markets is 1.18 and that for Portfolio 5 for all economies is 0.89 . The transaction costs are less than $0.5 \%$ for all countries and developed economies, and slightly higher for emerging markets, but none are more than $0.9 \%$ on an annual basis. The spot spread and forward spread are the end- 
of-month average bid-ask spread for each portfolio in basis points. The average spreads for emerging markets are higher than those of the developed economies, but the difference is not very large. Even for Portfolio 5, the difference in the average forward spreads between emerging markets and developed economies is still less than 40 basis points. The transaction cost for emerging markets is $7.5 \%(0.86 \%$ divided by $11.39 \%$ in the Emerging Markets Column H/L) of the H/L carry trade excess return.

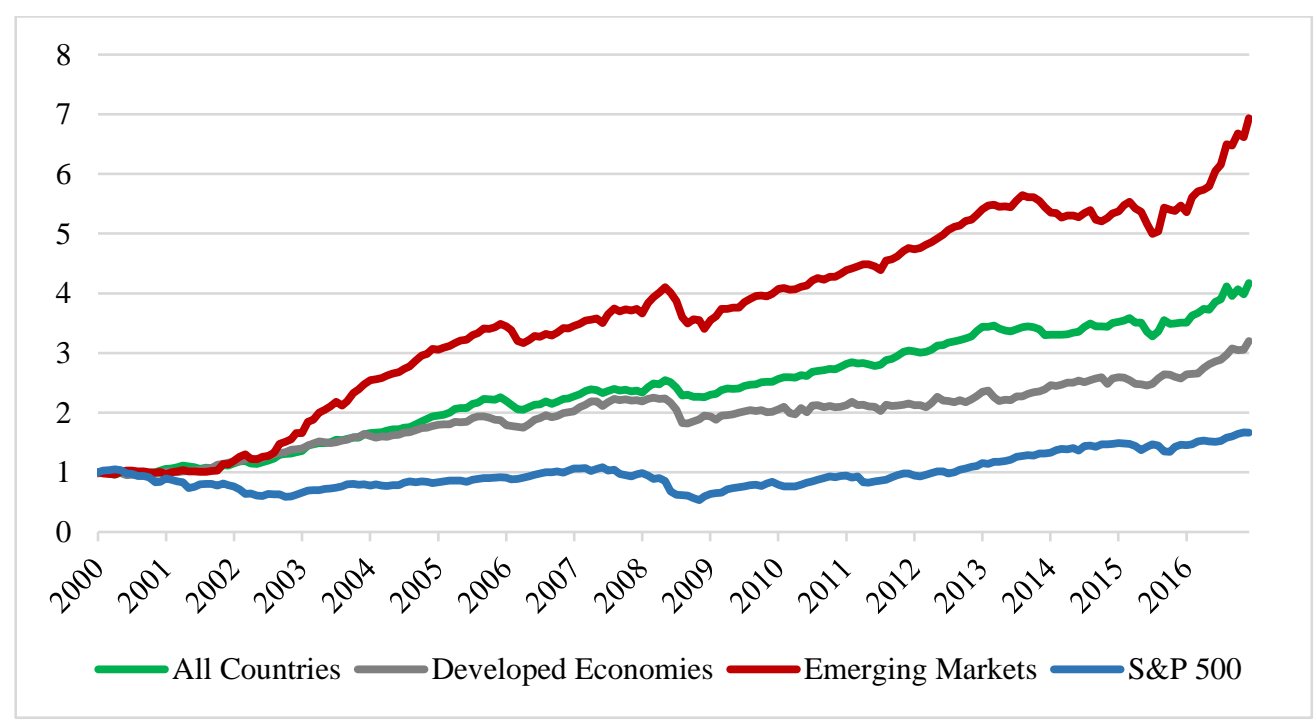

Figure 1: Cumulative Carry Trade Return

This figure shows cumulative excess returns on the carry trade portfolio, which is the returns on Portfolio 5 minus that on Portfolio 1. The red, grey, and green lines represent emerging markets, developed economies, and all countries, respectively. The blue line is the cumulative return on the S\&P 500 during the same period, from March 2000 to February 2017.

Figure 1 shows the cumulative carry trade returns from March 2000 to February 2017. The red, grey, and green lines represent emerging markets, developed economies, and all countries, respectively. The blue line indicates the S\&P 500 cumulative return. During the 17 years, the cumulative carry trade return for emerging markets is much higher than that of the S\&P 500 for the same period. 


\subsection{Volatility proxy}

I follow Menkhoff et al. (2012) method to construct a proxy for global FX volatility. I calculate the daily absolute $\log$ return $\left|r_{\tau}^{k}\right|=\left|\log S_{\tau}^{k}-\log S_{\tau-1}^{k}\right|$ of currency $k$ against USD on day $\tau$ and then take the average over all currencies available on day $\tau$. Then, I average the daily returns up to the monthly frequency. The global FX volatility proxy for the sample of all countries in month $t$ is:

$$
V O L_{t}=\sigma_{t}^{F X, A l l}=\frac{1}{T_{t}} \sum_{\tau \in T_{t}}\left[\sum_{k \in K_{\tau}}\left(\frac{\left|r_{\tau}^{k}\right|}{K_{\tau}}\right)\right]
$$

where $K_{\tau}$ is the number of available currencies on day $\tau$ and $T_{t}$ is the total number of trading days in month $t$. For currencies with missing data (missing spot or forward prices) during the month, I use only the currencies available to construct the monthly volatility proxy. I use absolute returns instead of squared returns to reduce the effects of outlier returns. I also construct the global FX volatility proxy $\sigma_{t}^{F X, \text { Developed }}$ for the sample of developed economies and $\sigma_{t}^{F X \text {,Emerging }}$ for the sample of emerging markets. Figure 2 plots the time series of the three volatility lines in purple, blue, and grey. As we can see, for example, the spikes of these lines coincide with the Global Financial Crisis in 2008 and the Euro Crisis in 2010 and 2011. There are spikes in 2000, 2004, 2013, and other years as well.

For the empirical analysis, similar to Menkhoff et al. (2012), I focus on the volatility innovations (denoted as $\triangle V O L_{t}$ or $\Delta \sigma_{t}^{F X}$ ) by taking the $\mathrm{AR}(1)$ regression of the time series of volatility:

$$
V O L_{t}=\beta V O L_{t-1}+\Delta V O L_{t} .
$$

The residues $\triangle V O L_{t}$ are the volatility innovations. This is a non-traded factor and the volatility innovations are uncorrelated with their own lags. I also calculate the volatility innovations for the developed and emerging markets separately. Figure 2 also plots the time series of the three volatility innovations using yellow, red, and green lines. 


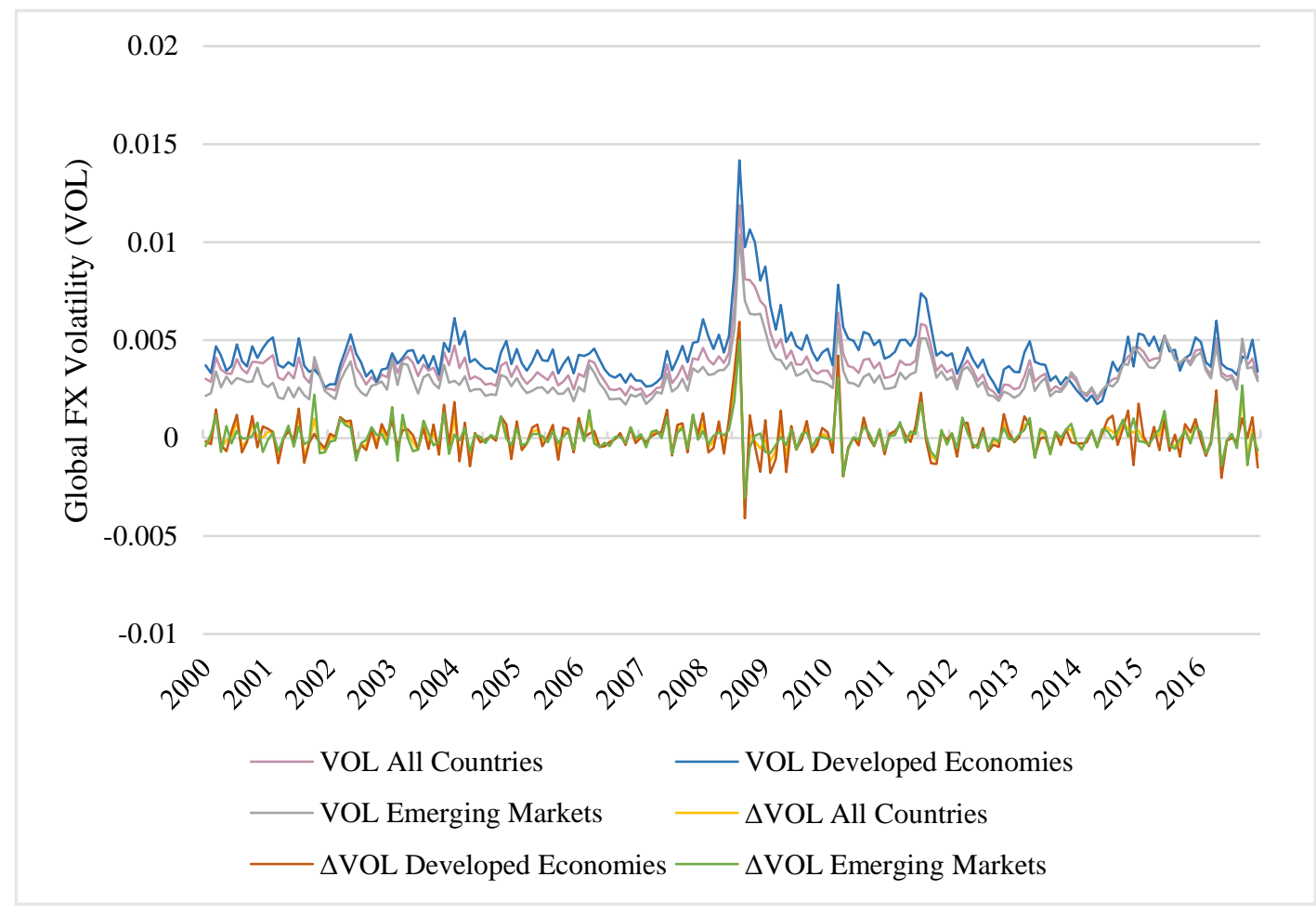

Figure 2: Global FX Volatility and Volatility Innovations

Figure 2 shows the time series plot of global FX volatility (VOL) and volatility innovations $(\triangle \mathrm{VOL})$ for all countries, developed economies, and emerging markets. The three upper lines (purple, blue, and grey) represent the global FX volatility for all countries, developed economies, and emerging markets, respectively. The three lower lines (yellow, red, and green) that start around zero are the volatility innovations for all countries, developed economies, and emerging markets, respectively. The time period is from March 2000 to February 2017.

\section{Empirical Results}

\subsection{Relationship between carry trade returns and volatility}

I provide a simple graphical illustration of the relationship between carry trade returns and global FX volatility innovations. I divide the $\mathrm{H} / \mathrm{L}$ carry trade returns on all countries into four groups. The first group contains the 25 percent of the months of carry trade returns with the lowest values of the sample's volatility innovations. The fourth group contains the 25 percent of the months of carry trade returns with the highest values of the sample's volatility innovations. The second and third group each contains the 25 percent of the months in between. Then, I take the average of the carry trade returns within each group. I do the same thing for developed economies only and for emerging markets only. 
For comparison, I also divide the currency carry trade returns on all countries, developed economies, and emerging markets separately into four groups based on G10 volatility innovations. Figure 3 illustrates the results. The top, middle, and bottom panels show the results for all countries, developed economies, and emerging markets, respectively. The blue bars in each panel show the average H/L carry trade returns on each group sorted by all countries, developed economies, or emerging markets volatility innovations separately. The red bars in each panel show the average H/L carry trade returns on each group sorted by G10 volatility innovations.
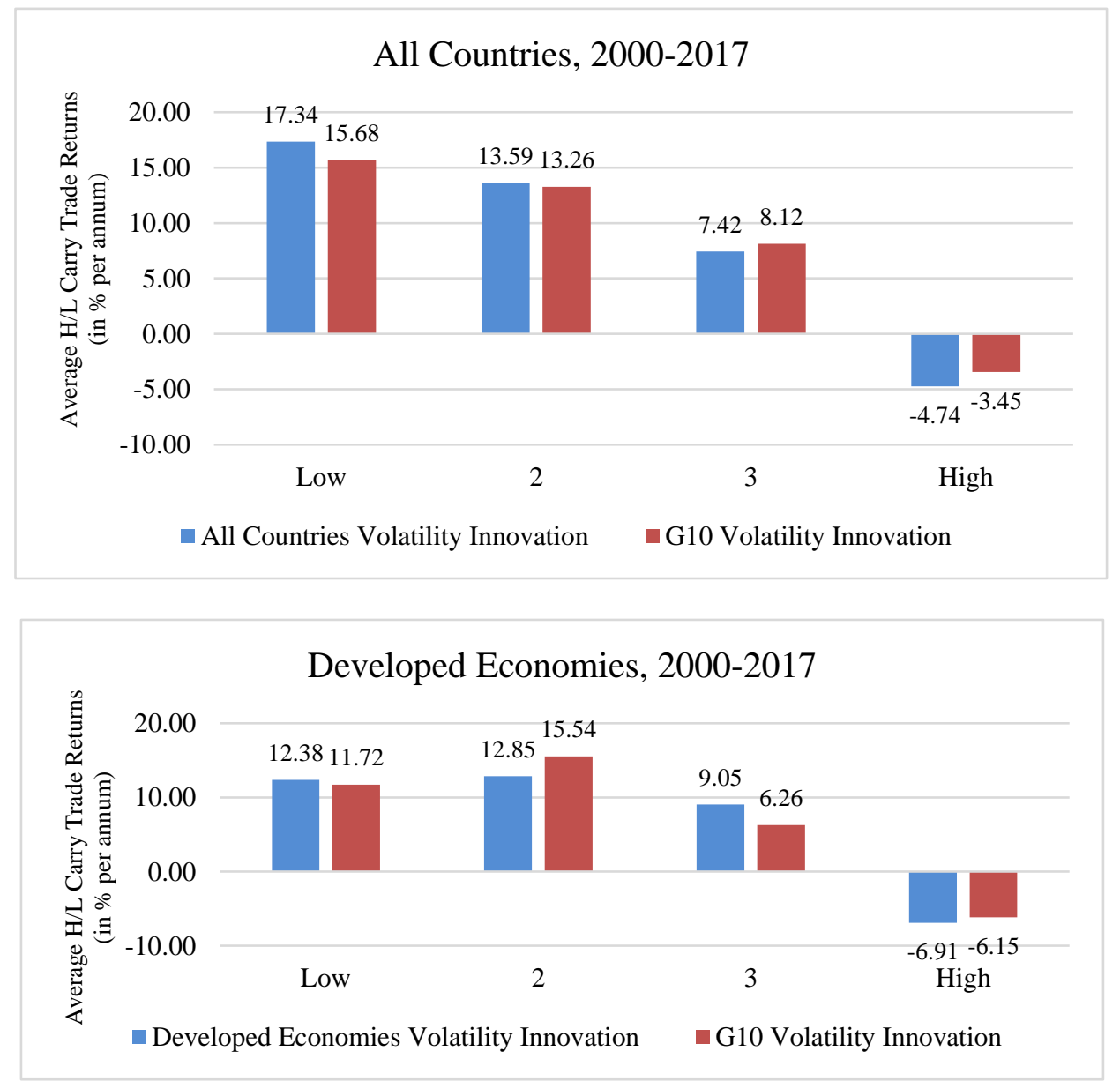


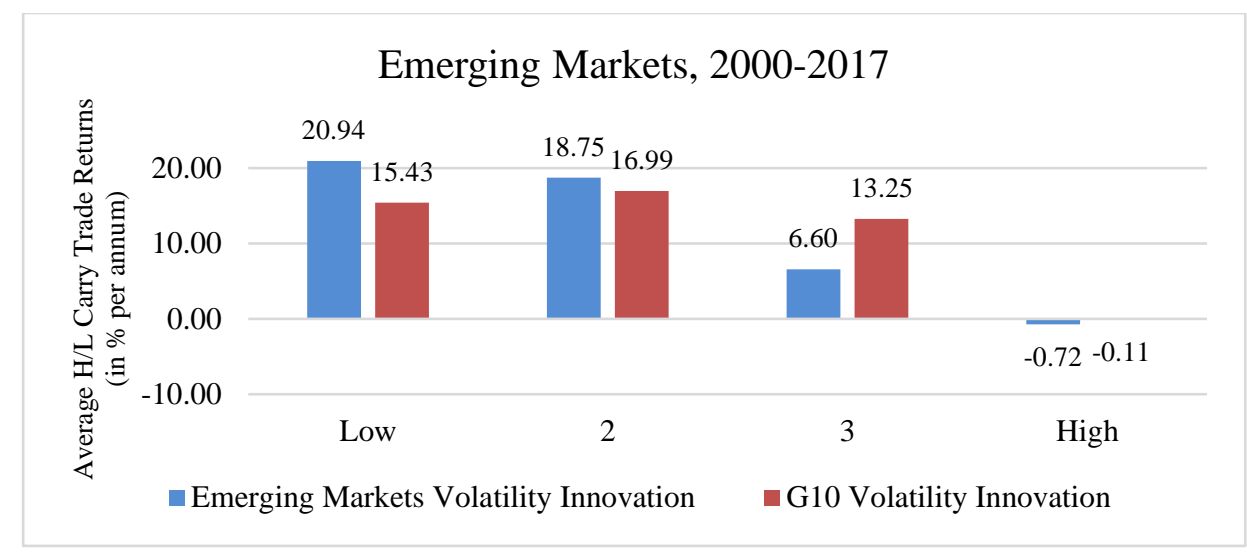

Figure 3: H/L Carry Trade Returns and Volatility

Figure 3 shows the mean annualized $\mathrm{H} / \mathrm{L}$ carry trade portfolio returns conditional on volatility innovations sorted by the lowest 25 percent quintile to the highest 25 percent quintile (four categories from "Low" to High" on the x-axis of each panel). The H/L carry trade portfolio goes long on Portfolio 5 (highest forward discount) and short on Portfolio 1 (lowest forward discount). The top, middle, and bottom panels show the results for all countries, developed economies, and emerging markets, respectively. The blue bars indicate the mean carry trade returns conditional on the sample volatility innovations and the red bars are the mean carry trade returns conditional on G10 volatility innovations. The G10 countries are the Euro area, Japan, the United Kingdom, Australia, Canada, Switzerland, Sweden, New Zealand, Norway, and Denmark. USD is the base currency. The sample period is from March 2000 to February 2017.

As Figure 3 shows, the H/L carry trade portfolio generates high returns during periods of low volatility innovations and low returns during periods of high volatility innovations. For all countries, the return decreases monotonically as volatility innovation increases. For developed economies or emerging markets alone, the monotonicity is less than that of all countries. High interest rate currencies perform poorly and low interest rate currencies perform well in times of high volatility innovations. This is almost in line with Menkhoff et al. (2012) findings. The major difference between my results and those reported in the literature, is that the average $\mathrm{H} / \mathrm{L}$ carry trade return for Group High of emerging markets is much higher than that for developed economies, whether conditioning on the sample's volatility innovations or on G10 volatility innovations. During periods of high volatility innovations (refer to Group High for both the sample's volatility innovations and G10 volatility innovations), the average H/L carry trade returns for emerging markets are close to zero, whereas the returns for developed economies are below minus 6 percent and the returns for all countries are in between. This result indicates that when volatility innovations are high, the high interest rate currencies of emerging markets as a whole do not depreciate as much as those of developed economies do and/or the low interest rate currencies of emerging markets 
do not appreciate as much as those of developed economies do. This finding is new to the literature. The following section tests this finding more rigorously.

\subsection{Simple hypothesis test}

This section tests the average return of carry trade portfolio during periods of high volatility innovations (e.g., Group High in Figure 3). The null hypothesis is that H/L carry trade returns during periods of high volatility innovations are zero. In addition to the 4 groups in Figure 3, I also sort the H/L carry trade returns on all countries, developed economies, and emerging markets separately into 5, 6, 7, and 8 groups by volatility innovations. Table 2 presents the results. The row "Top 1/4 quintile" shows the average of the highest $1 / 4$ quintile of annualized H/L carry trade portfolio returns for all countries, developed economies, and emerging markets sorted separately by each sample's volatility innovations (High $\Delta$ VOL) and by G10 volatility innovations (High G10 $\Delta$ VOL). This is the average $\mathrm{H} / \mathrm{L}$ carry trade return during months of high volatility innovations, in which I sort all returns into 4 groups, as in Figure 3. Similarly, the rows "Top 1/5 quintile," "Top 1/6 quintile," "Top 1/7 quintile," and "Top 1/8 quintile" show the mean of the highest $1 / 5,1 / 6,1 / 7$, and 1/8 quintile, respectively, of the annualized H/L carry trade portfolio returns on all countries, developed economies, and emerging markets sorted separately by their samples' volatility innovations (High $\Delta$ VOL) and by G10 volatility innovations (High G10 $\Delta$ VOL).

As Table 2 reports, the average top 1/4 to 1/8 quintiles of carry trade returns for developed economies sorted by its sample volatility innovations and G10 volatility innovations gradually become significantly negative ( $90 \%$ confidence). However, for emerging markets, the average is insignificant for the top 1/4 to 1/8 quintiles sorted both by its own volatility innovations and by $\mathrm{G} 10$ volatility innovations. For all countries, the results are mixed. The average top $1 / 4$ to $1 / 8$ quintiles of carry trade returns gradually become highly significantly negative (95\% confidence) sorted by its own volatility innovations, but remain insignificant sorted by G10 volatility innovations.

Table 2 reports the simple hypothesis test results of the mean returns on the H/L carry trade portfolio during periods of high volatility innovations. The null hypothesis is that the average $\mathrm{H} / \mathrm{L}$ carry trade return during periods of high volatility innovations is zero. The row "Top 1/4 quintile," "Top 1/5 quintile," "Top 1/6 quintile," "Top 1/7 quintile," and "Top 1/8 quintile" show, respectively, the mean of the highest $1 / 4,1 / 5,1 / 6,1 / 7$, and $1 / 8$ quintile of the $\mathrm{H} / \mathrm{L}$ carry trade portfolio returns for all countries, developed economies, and emerging markets, sorted separately by their sample volatility innovations (High $\triangle \mathrm{VOL}$ ) and by G10 volatility innovations (High G10 $\Delta$ VOL). T statistics and P-values are also reported. The sample period is from March 2000 to February 2017. Monthly transaction cost adjusted returns are used. All returns are annualized. 
Table 2: Simple Hypothesis Test Results

\begin{tabular}{|c|c|c|c|c|c|c|c|}
\hline \multicolumn{8}{|c|}{$\begin{array}{c}\text { Simple Hypothesis Test } \\
\mathrm{H}_{0} \text { : The average } \mathrm{H} / \mathrm{L} \text { carry trade return during periods of high volatility } \\
\text { innovations }=0\end{array}$} \\
\hline & & \multicolumn{2}{|c|}{ All Countries } & \multicolumn{2}{|c|}{ Developed Economies } & \multicolumn{2}{|c|}{ Emerging Markets } \\
\hline & & $\begin{array}{c}\text { High } \\
\Delta \mathrm{VOL}\end{array}$ & $\begin{array}{l}\text { High } \\
\text { G10 } \\
\Delta \mathrm{VOL}\end{array}$ & $\begin{array}{c}\text { High } \\
\Delta \mathrm{VOL}\end{array}$ & $\begin{array}{c}\text { High } \\
\text { G10 } \\
\triangle \mathrm{VOL} \\
\end{array}$ & $\begin{array}{c}\text { High } \\
\Delta \mathrm{VOL}\end{array}$ & $\begin{array}{c}\text { High } \\
\text { G10 } \\
\Delta \text { VOL }\end{array}$ \\
\hline \multirow{3}{*}{$\begin{array}{l}\text { Top } \\
1 / 4 \\
\text { quintile }\end{array}$} & Mean & $-4.74 \%$ & $-3.45 \%$ & $-6.91 \%$ & $-6.15 \%$ & $-0.72 \%$ & $-0.11 \%$ \\
\hline & $\mathrm{t}$ & -1.341 & -1.080 & -1.463 & -1.311 & -0.160 & -0.032 \\
\hline & $\mathrm{p}$-value & 0.186 & 0.285 & & 0.196 & 0.873 & 0.975 \\
\hline \multirow{3}{*}{$\begin{array}{l}\text { Top } 1 / 5 \\
\text { quintile }\end{array}$} & Mean & $-6.55 \%$ & $-4.39 \%$ & $-9.10 \%$ & $-9.86 \%$ & $-0.35 \%$ & $-1.66 \%$ \\
\hline & $\mathrm{t}$ & -1.665 & -1.195 & -1.632 & -1.780 & -0.063 & -0.414 \\
\hline & $\mathrm{p}$-value & 0.104 & 0.239 & 0.111 & 0.083 & 0.950 & 0.681 \\
\hline \multirow{3}{*}{$\begin{array}{l}\text { Top } 1 / 6 \\
\text { quintile }\end{array}$} & Mean & $-9.34 \%$ & $-6.50 \%$ & $-13.00 \%$ & $-12.87 \%$ & $0.00 \%$ & $-3.96 \%$ \\
\hline & $\mathrm{t}$ & -2.117 & -1.581 & -2.030 & -1.997 & 0.000 & -0.873 \\
\hline & $\mathrm{p}$-value & 0.042 & 0.123 & 0.051 & 0.054 & 1.000 & 0.389 \\
\hline \multirow{3}{*}{$\begin{array}{l}\text { Top } 1 / 7 \\
\text { quintile }\end{array}$} & Mean & $-11.24 \%$ & $-6.43 \%$ & $-13.39 \%$ & $-13.75 \%$ & $-6.27 \%$ & $-2.94 \%$ \\
\hline & $\mathrm{t}$ & -2.333 & -1.400 & -1.782 & -1.885 & -1.010 & -0.621 \\
\hline & p-value & 0.027 & 0.173 & 0.086 & 0.070 & 0.321 & 0.540 \\
\hline \multirow{3}{*}{$\begin{array}{l}\text { Top 1/8 } \\
\text { quintile }\end{array}$} & Mean & $-13.05 \%$ & $-6.22 \%$ & $-14.54 \%$ & $-15.39 \%$ & $-5.40 \%$ & $-2.23 \%$ \\
\hline & $\mathrm{t}$ & -2.497 & -1.244 & -1.799 & -1.909 & -0.898 & -0.424 \\
\hline & $\mathrm{p}$-value & 0.020 & 0.225 & 0.084 & 0.068 & 0.378 & 0.675 \\
\hline
\end{tabular}

\subsection{Regression analysis}

This section briefly summarizes my approach to cross-sectional asset pricing. I use the Fama-MacBeth two-pass ordinary least squares (OLS) methodology to estimate portfolio betas and factor risk prices. The simplified two-pass procedure follows Chapter 12 of Cochrane (2005). I use a first-step time series regression to obtain the full sample betas for each portfolio $i$. I then use these betas in the second step crosssectional regression of average portfolio returns on the betas to estimate factor prices $\lambda$. The regression equations are:

$$
\begin{gathered}
r x_{t}^{i}=\alpha+\beta_{D O L}^{i} D O L_{t}+\beta_{\Delta V O L_{-} G 10}^{i} \Delta V O L_{-} G 10_{t}+\varepsilon_{t} \\
r x^{i}=C+\lambda_{D O L} \beta_{D O L}^{i}+\lambda_{\Delta V O L_{-} G 10} \beta_{\Delta V O L_{-} G 10}^{i}+\xi^{i}
\end{gathered}
$$

where equation (4) is the time series regression and equation (5) is the crosssectional regression. $\alpha$ and $C$ are constants. $r x_{t}^{i}$ is the excess return on Portfolio $i$ for month $t$ and $r x^{i}$ denotes the average excess return of Portfolio $i$ for all months. The factors are DOL and $\triangle$ VOL_G10. $\lambda_{D O L}$ is the factor price of DOL and $\lambda_{\triangle V O L_{-} G 10}$ is the factor price of G10 volatility innovations. The DOL factor is the average return of the five portfolios. The $\Delta \mathrm{VOL} \_\mathrm{G} 10$ factor is the G10 volatility 
innovations factor. I also replace $\Delta \mathrm{VOL} \_\mathrm{G} 10$ with $\Delta \mathrm{VOL}$, which is the sample's volatility innovations, and find similar results from the regressions. I report the regression statistics of equations (4) and (5) in Table 3.

Table 3: Cross-sectional Asset Pricing Results: Volatility Risk

\begin{tabular}{|c|c|c|c|c|c|c|c|c|c|c|c|c|c|c|}
\hline \multicolumn{15}{|c|}{ Panel A: Factor Betas } \\
\hline \multicolumn{5}{|c|}{ All Countries (with b-a) } & \multicolumn{5}{|c|}{ Developed Economies (with b-a) } & \multicolumn{5}{|c|}{ Emerging markets (with b-a) } \\
\hline $\mathrm{PF}$ & $\alpha$ & DOL & $\begin{array}{c}\Delta \mathrm{VOL}_{-} \\
\mathrm{G} 10\end{array}$ & $\mathrm{R}^{2}$ & $\mathrm{PF}$ & $\alpha$ & DOL & $\begin{array}{c}\Delta \mathrm{VOL} \\
\text { G10 }\end{array}$ & $\mathrm{R}^{2}$ & $\mathrm{PF}$ & $\alpha$ & DOL & $\begin{array}{c}\Delta \mathrm{VOL} \\
\mathrm{G} 10\end{array}$ & $\mathrm{R}^{2}$ \\
\hline \multirow[t]{3}{*}{1} & -0.003 & 0.811 & 2.310 & 0.75 & 1 & -0.003 & 0.771 & 3.149 & 0.71 & 1 & -0.002 & 0.466 & 0.504 & 0.49 \\
\hline & $(0.001)$ & $(0.038)$ & $(0.479)$ & std & & $(0.001)$ & $(0.048)$ & $(0.909)$ & std & & $(0.000)$ & $(0.045)$ & $(0.441)$ & std \\
\hline & -5.42 & 21.32 & 4.82 & $\mathrm{t}$ & & -3.85 & 15.92 & 3.46 & $\mathrm{t}$ & & -3.06 & 10.43 & 1.14 & $\mathrm{t}$ \\
\hline \multirow[t]{3}{*}{2} & -0.002 & 0.953 & -0.041 & 0.88 & 2 & -0.002 & 0.935 & 0.577 & 0.81 & 2 & -0.001 & 0.719 & -0.798 & 0.67 \\
\hline & $(0.000)$ & $(0.031)$ & $(0.389)$ & std & & $(0.001)$ & $(0.057)$ & $(0.765)$ & std & & $(0.001)$ & $(0.056)$ & $(0.629)$ & std \\
\hline & -4.22 & 30.74 & -0.10 & $\mathrm{t}$ & & -2.62 & \begin{tabular}{|l}
6.35 \\
\end{tabular} & 0.75 & $\mathrm{t}$ & & -0.99 & 12.78 & -1.27 & $\mathrm{t}$ \\
\hline \multirow[t]{3}{*}{3} & 0.000 & 1.113 & -0.304 & 0.89 & 3 & 0.001 & 1.028 & -0.650 & 0.84 & 3 & -0.003 & 1.129 & 0.082 & 0.70 \\
\hline & $(0.000)$ & $(0.034)$ & $(0.553)$ & std & & $(0.001)$ & $(0.041)$ & $(0.736)$ & std & & $(0.001)$ & $(0.070)$ & $(0.786)$ & std \\
\hline & -0.25 & 32.42 & -0.55 & $\mathrm{t}$ & & 2.09 & 25.29 & -0.88 & $\mathrm{t}$ & & -3.18 & 16.12 & 0.10 & $\mathrm{t}$ \\
\hline \multirow[t]{2}{*}{4} & 0.001 & 1.141 & -0.096 & 0.84 & 4 & 0.000 & \begin{tabular}{|l}
1.094 \\
\end{tabular} & -0.675 & 0.89 & 4 & -0.001 & 1.493 & 0.865 & 0.75 \\
\hline & $(0.001)$ & $(0.051)$ & $(0.749)$ & std & & $(0.001)$ & $(0.031)$ & $(0.627)$ & std & & $(0.001)$ & $(0.074)$ & $(0.916)$ & std \\
\hline \multicolumn{15}{|c|}{ Table 3 Continued } \\
\hline & 1.80 & 22.45 & -0.13 & $\mathrm{t}$ & & 0.12 & 35.40 & -1.08 & $\mathrm{t}$ & & -1.32 & 20.11 & 0.95 & $\mathrm{t}$ \\
\hline \multirow[t]{3}{*}{5} & 0.004 & 0.989 & -2.002 & 0.67 & 5 & 0.003 & \begin{tabular}{|l|l|} 
& \\
\end{tabular} & -2.546 & 0.82 & 5 & \begin{tabular}{|l|}
0.007 \\
\end{tabular} & 1.303 & -0.546 & 0.56 \\
\hline & $(0.001)$ & $(0.064)$ & $(0.871)$ & std & & $(0.001)$ & $(0.051)$ & $(0.920)$ & std & & $(0.001)$ & $(0.112)$ & (1.078) & std \\
\hline & 4.69 & 15.55 & -2.30 & $\mathrm{t}$ & & 3.59 & 22.69 & -2.77 & $\mathrm{t}$ & & 5.06 & 11.68 & -0.51 & $\mathrm{t}$ \\
\hline \multirow[t]{3}{*}{$\mathrm{H} / \mathrm{L}$} & 0.007 & 0.178 & -4.312 & 0.13 & $\mathrm{H} / \mathrm{L}$ & 0.006 & \begin{tabular}{|l|l|}
0.377 \\
\end{tabular} & -5.695 & 0.30 & $\mathrm{H} / \mathrm{L}$ & 0.008 & \begin{tabular}{|l|}
0.837 \\
\end{tabular} & -1.050 & 0.28 \\
\hline & $(0.001)$ & $(0.077)$ & $(1.205)$ & std & & $(0.001)$ & $(0.075)$ & $(1.577)$ & std & & $(0.002)$ & $(0.135)$ & $(1.232)$ & std \\
\hline & 5.88 & 2.31 & -3.58 & $\mathrm{t}$ & & 4.44 & 5.05 & -3.61 & $\mathrm{t}$ & & 5.26 & 6.19 & -0.85 & $\mathrm{t}$ \\
\hline \multicolumn{15}{|c|}{ Panel B: Factor Prices (Fama-MacBeth) } \\
\hline \multicolumn{4}{|c|}{ All Countries (with b-a) } & \multicolumn{5}{|c|}{ Developed Economies (with b-a) } & \multicolumn{6}{|c|}{ Emerging markets (with b-a) } \\
\hline $\begin{array}{c}\mathrm{FM} \\
\mathrm{B}\end{array}$ & $\mathrm{C}$ & DOL & $\begin{array}{c}\Delta \mathrm{VOL}_{-} \\
\mathrm{G} 10\end{array}$ & FM & MB & $\mathrm{C}$ & DOL & $\begin{array}{c}\Delta \text { VOL } \\
\text { G10 }\end{array}$ & FM & MB & $\mathrm{C}$ & DOL & $\mathrm{L}_{-}$ & G10 \\
\hline$\lambda$ & 0.000 & 0.001 & -0.002 & $\lambda$ & $\lambda$ & 0.010 & -0.009 & -0.002 & $\lambda$ & $\lambda$ & -0.004 & 0.006 & -0.0 & 003 \\
\hline std & $(0.007)$ & $(0.007)$ & $(0.001)$ & stc & td & $(0.011)$ & $(0.010)$ & $(0.001)$ & stc & $\mathrm{td}$ & $(0.004)$ & $(0.004)$ & $(0.00$ & 03) \\
\hline $\mathrm{t}$ & 0.04 & 0.21 & -2.67 & & $\mathrm{t}$ & 0.91 & -0.84 & -1.99 & $\mathrm{t}$ & $\mathrm{t}$ & -1.02 & 1.53 & -1.0 & 03 \\
\hline $\mathrm{R}^{2}$ & 0.79 & & & $\mathrm{R}$ & $2^{2}$ & 0.88 & & & $\mathrm{R}^{2}$ & $2^{2}$ & 0.53 & & & \\
\hline
\end{tabular}

Table 3 reports the cross-sectional asset pricing results for the linear factor model based on the dollar risk factor (DOL) and G10 volatility innovations ( $\triangle$ VOL_G10). 
The test assets are excess returns on five dollars carry trade portfolios (PF, and Portfolios 1 to 5) and the H/L carry trade portfolio (Portfolio H/L). Panel A reports results for the time series regressions of excess returns on a constant $(\alpha)$, the dollar risk factor (DOL), and the G10 volatility innovations ( $\left.\triangle \mathrm{VOL} \_\mathrm{G} 10\right)$. Panel B reports the coefficient estimates of a constant $(C)$, factor prices $(\lambda)$ of the dollar risk factor (DOL), and the G10 volatility innovations ( $\triangle$ VOL_G10) with the simplified FamaMacBeth cross-sectional regression on average returns. The factor betas obtained from time series regressions in Panel A are used in the cross-sectional regressions in Panel B. The results in Panels A and B are for all countries (left), developed economies (middle), and emerging markets (right). HAC standard errors with Newey-West adjustments with optimal lag selection by Andrews (1991) are reported in parentheses. The sample period is from March 2000 to February 2017. Monthly transaction cost adjusted returns are used.

Panel A reports the results for the time series regressions of excess returns sorted by forward discounts on a constant $(\alpha)$, DOL, and G10 volatility innovations $(\Delta$ VOL_G10). In parentheses, I report the HAC standard errors with Newey-West adjustments with optimal lag selection by Andrews (1991). The results are for the full sample countries, the developed economies sample, and the emerging markets sample. The estimates of $\beta_{\triangle V O L_{-} G 10}$ are large, negative, and significant for Portfolio 5 and Portfolio $\mathrm{H} / \mathrm{L}$ for developed economies, but small and insignificant for Portfolio 5 and Portfolio $\mathrm{H} / \mathrm{L}$ for emerging markets. There is also a monotonic decline in the beta of G10 volatility innovations for developed economies, but it is less monotonic for all countries or emerging markets.

Panel B reports the coefficient estimates of the factor prices $(\lambda)$ of DOL and G10 volatility innovations ( $\triangle$ VOL_G10) using the Fama-MacBeth (FMB) crosssectional regression. I use the factor betas obtained from time series regressions in Panel A in the simplified FMB cross-sectional regression in Panel B. The crosssectional regression also includes a constant (C). In parentheses, I report the HAC standard errors with Newey-West adjustments with optimal lag selection by Andrews (1991). The factor price of G10 volatility innovations ( $\triangle \mathrm{VOL}$ G10) is significantly negative for developed economies and all countries, but insignificant for emerging markets. The negative factor price estimate indicates that portfolios with negative covariance with volatility innovations require a risk premium.

Instead of regressing on G10 volatility innovations, I also regress the carry trade returns on a constant, DOL, and the sample's volatility innovations. The results are similar.

To summarize, Panels A and B together show that the explanatory power of volatility innovations is significant for all countries and developed economies, but insignificant for emerging markets. This result is also in contrast to those reported by Menkhoff et al. (2012).

An interesting question is why my results differ. I think that the key difference is that my sample countries, especially the emerging markets, are different from Menkhoff et al. (2012). Out of the 48 countries Menkhoff et al. (2012) include in their study, there are only 17 emerging markets, 7 of which are free floating. 
However, the data for my study consists of 40 emerging markets, about two thirds of which are NOT free floating. This leads to a different result. I dig deeper into the emerging markets in the following section.

\subsection{A closer look at emerging market carry trade and volatility}

To further analyze this particular finding for emerging market carry trade, I select 28 emerging markets that are easy to classify, have long periods of data, and are geographically diversified from the 40 emerging markets and divide them into three categories based on their currency regimes. To balance the weighting effects of the portfolio, I combine each category with G10 countries to form three groups. The first group contains the $\mathrm{G} 10$ countries and 8 free-float emerging markets (free-float carry trade). The second group contains the G10 countries and 10 managed-float emerging markets (managed-float carry trade). The third group contains the G10 countries and 10 fixed-rate emerging markets (fixed-rate carry trade). The selection criteria follows the IMF's de facto classification of exchange rate regime. From 2009 to 2016, there are 10 classifications in the IMF's Annual Report on Exchange Arrangements and Exchange Restrictions (2009, 2010, 2011, 2012, 2013, 2014, 2015 and 2016 respectively). I classify "No separate legal tender," "Currency board," "Conventional peg," "Stabilized arrangement," and "Crawling peg" as fixed-rate currency regimes; "Craw-like arrangement," "Pegged exchange rate within horizontal bands," and "Other managed arrangement" as managed-float currency regimes; and "Floating" and "Free floating" as free-float currency regimes. Since the IMF changed to the current regime definitions in 2009, I classify countries categorized as "Floating" after 2009 but as "Managed floating with no predetermined path for the exchange rate" before 2009 as managed-float currency regimes. The IMF's country list in each category changes annually; therefore, I use the country's most frequently category from 2009 to 2016 or from the year in which its data becomes available as its exchange rate regime classification. Table 4 presents the exchange rate regime classification. Of note, Kazakhstan moves between "Stabilized arrangement" and "Craw-like arrangement" on a de facto basis for 2010 to 2015, but behaves more like a "Stabilized arrangement." Therefore, I still treat it as a fixed-rate currency regime. 
Table 4: G10 countries, Free-Float, Managed-Float and Fixed-Rate Currency Regimes

\begin{tabular}{|l|l|l|l|}
\hline G10 Countries & $\begin{array}{l}\text { 8 Free-Float } \\
\text { Emerging } \\
\text { Markets }\end{array}$ & $\begin{array}{l}\text { 10 Managed-Float } \\
\text { Emerging } \\
\text { Markets }\end{array}$ & $\begin{array}{l}\text { 10 Fixed-Rate } \\
\text { Emerging } \\
\text { Markets }\end{array}$ \\
\hline Euro area & Mexico & China & Saudi Arabia \\
\hline Japan & Turkey & Russia & Kazakhstan \\
\hline UK & Brazil & India & Bulgaria \\
\hline Australia & South Africa & Thailand & Kuwait \\
\hline Canada & Poland & Malaysia & Qatar \\
\hline Switzerland & Philippines & Ghana & Sri Lanka \\
\hline Sweden & Indonesia & Romania & Morocco \\
\hline New Zealand & Chile & Colombia & Vietnam \\
\hline Norway & & Peru & Ukraine \\
\hline Denmark & & Argentina & $\begin{array}{l}\text { United Arab } \\
\text { Emirates }\end{array}$ \\
\hline
\end{tabular}

Table 4 reports the exchange rate regime classification for the emerging markets. The selection criteria is based on the IMF's de facto exchange rate regime classification. From 2009 to 2016, there are 10 classifications in the IMF's Annual Report on Exchange Arrangements and Exchange Restrictions. I classify "No separate legal tender," "Currency board," "Conventional peg," "Stabilized arrangement," and "Crawling peg" as fixed-rate currency regimes; "Craw-like arrangement," "Pegged exchange rate within horizontal bands," and "Other managed arrangement" as managed-float currency regimes; and "Floating" and "Free-floating" as free-float currency regimes. The IMF switched to the current regime classification in 2009. Consequently, countries categorized as "Floating" after 2009 but as "Managed floating with no pre-determined path for the exchange rate" before 2009 are classified as managed-float currency regimes. Since the IMF's country list in each category changes annually, the country's most frequent classification from 2009 to 2016 or from the year when its data becomes available is used as its exchange rate regime classification.

Similar to Section 4.1, I provide three simple graphical illustrations of the relationship between carry trade returns and volatility innovations. The first illustration consists of carry trade returns for the G10 countries and 8 free-float emerging markets (free-float carry trade). The second illustration consists of carry trade returns for G10 countries and 10 managed-float emerging markets (managedfloat carry trade). The third illustration consists of carry trade returns for the G10 countries and 10 fixed-rate emerging markets (fixed-rate carry trade). For each illustration, I divide the average $\mathrm{H} / \mathrm{L}$ carry trade returns into four groups. The first group contains the 25 percent of the months of carry trade returns with the lowest values of the sample's volatility innovations. The fourth group contains the 25 percent of the months of carry trade returns with the highest values of the sample's 
volatility innovations. The second and third group each contains the 25 percent of the months in between. Then, I take the average carry trade returns within each group. I also sort the months by G10 volatility innovations for comparison.

Figure 4 shows the results. The top, middle, and bottom panels provide the results for the G10 countries and 8 free-float emerging markets, the G10 countries and 10 managed-float emerging markets, and the G10 countries and 10 fixed-rate emerging markets.

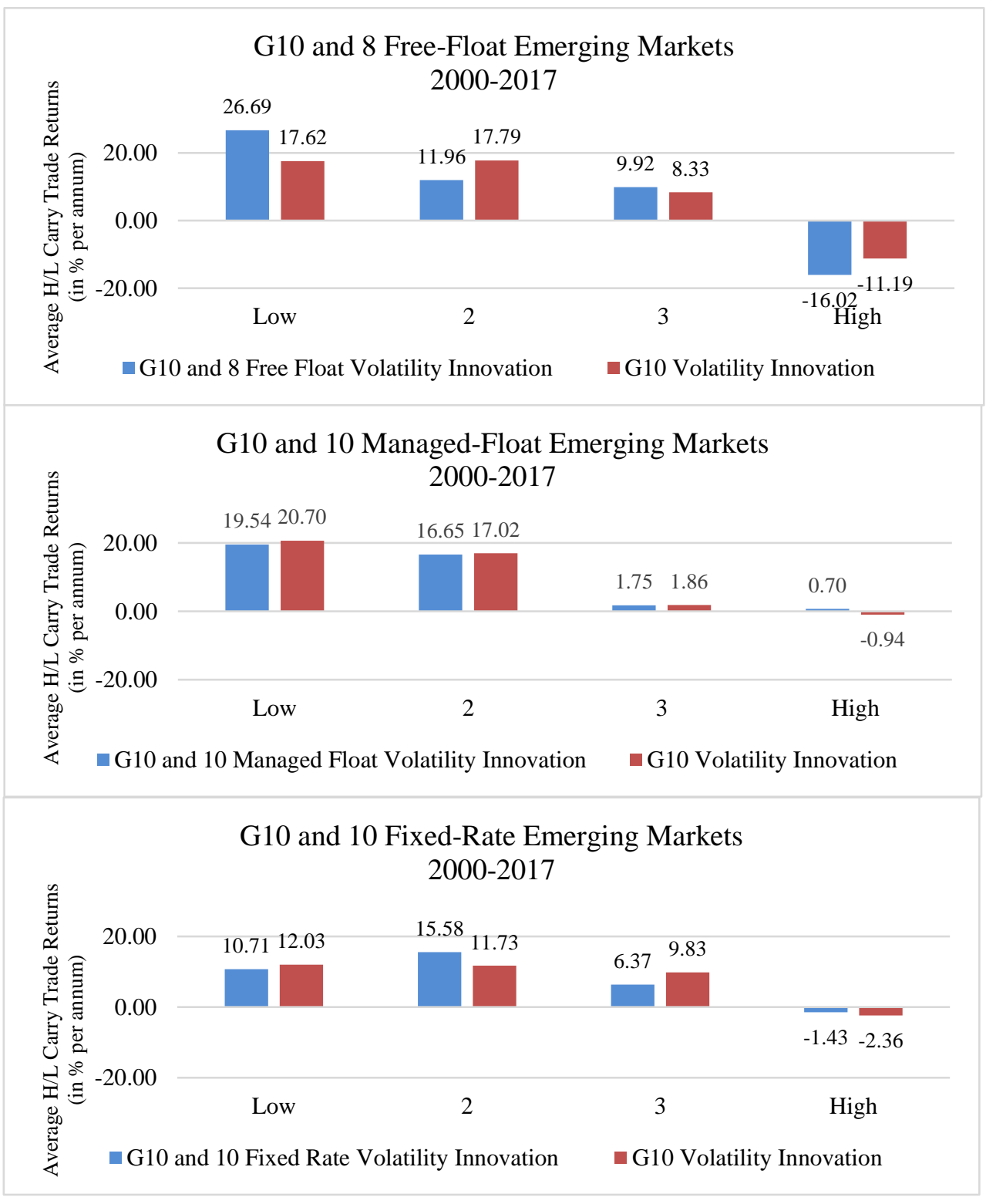

Figure 4: Carry Trade Returns and Volatility by Currency Regime 
Figure 4 shows the mean annualized H/L carry trade portfolio returns for different currency regimes conditional on volatility innovations sorted by the lowest 25 percent quintile to the highest 25 percent quintile (four categories from "Low" to High" on the $\mathrm{x}$-axis of each panel). The $\mathrm{H} / \mathrm{L}$ carry trade portfolio goes long on Portfolio 5 (highest forward discount) and short on Portfolio 1 (lowest forward discount). The top, middle, and bottom panels show the results for the G10 countries and 8 free-float emerging markets, G10 countries and 10 managed-float emerging markets, and G10 countries and 10 fixed-rate emerging markets, respectively. The blue bars indicate the mean carry trade returns conditional on the sample volatility innovations. The red bars represent the mean carry trade returns conditional on G10 volatility innovations. The G10 countries are the Euro area, Japan, the United Kingdom, Australia, Canada, Switzerland, Sweden, New Zealand, Norway, and Denmark. The 8 free-float emerging markets are Mexico, Turkey, Brazil, South Africa, Poland, the Philippines, Indonesia, and Chile. The 10 managed-float emerging markets are China, Russia, India, Thailand, Malaysia, Ghana, Romania, Colombia, Peru, and Argentina. The 10 fixed-rate emerging markets are Saudi Arabia, Kazakhstan, Bulgaria, Kuwait, Qatar, Sri Lanka, Morocco, Vietnam, Ukraine, and the United Arab Emirates. USD is the base currency. The sample period is from March 2000 to February 2017.

We can also see some monotonic relations between carry trade returns and volatility. As volatility innovations increase, carry trade returns decrease for all three groups. During periods of high volatility innovations, the average carry trade return on the G10 and 8 free-float emerging markets is negative and large, similar to the developed economies in Figure 3. The average return of the G10 and 8 free-float emerging markets during periods of high volatility innovations is $-16.02 \%$, conditioning on its sample volatility innovations, and $-11.19 \%$ on G10 volatility innovations. However, for the managed-float or fixed-rate regimes, the results are different. The carry trade returns are very small or close to zero in periods of high volatility innovations. The average return of the G10 and 10 managed-float emerging markets during periods of high volatility innovations is $0.7 \%$, conditioning on its sample volatility innovations, and $-0.94 \%$ on G10 volatility innovations. The average return on the G10 and 10 fixed-rate emerging markets during periods of high volatility innovations is $-1.43 \%$, conditioning on its sample volatility innovations, and $-2.36 \%$ on G10 volatility innovations.

The return difference between managed- and free-float carry trades is $16.72 \%$ in periods of high sample volatility innovations. Its one-sided p-value is $1.3 \%$, which is highly significant. The return difference is $10.25 \%$ in periods of high G10 volatility innovation. Its one-sided p-value is $5.3 \%$, which is also significant. Similarly, the return differences between the fixed-rate and free-float carry trades are also significant under both volatility measures.

Table 5 presents the null hypothesis test for the average carry trade returns during periods of high volatility innovations. Similar to Table 2 , the null hypothesis is that the average $\mathrm{H} / \mathrm{L}$ carry trade return during periods of high volatility innovations is 
zero. The row "Top 1/4 quintile," “Top 1/5 quintile," "Top 1/6 quintile," “Top 1/7 quintile," and "Top $1 / 8$ quintile" show, respectively, the mean of the highest $1 / 4$, $1 / 5,1 / 6,1 / 7$, and 1/8 quintiles of the annualized free-float, managed-float, and fixed-rate carry trade portfolio returns sorted separately by their sample volatility innovations (High $\Delta$ VOL) and by G10 volatility innovations (High G10 $\Delta$ VOL). As we can see from Table 5, the average H/L carry trade returns on the G10 and 8 free-float emerging markets during periods of high volatility innovations are highly significantly negative. The results are mostly in the 95 percent confidence interval, and some are close to 99 percent confidence, whether conditional on the sample's volatility innovations or on G10 volatility innovations. However, the average H/L carry trade returns on the G10 and 10 managed-float emerging markets during periods of high volatility innovations are insignificant. The average $\mathrm{H} / \mathrm{L}$ carry trade returns on the G10 and 10 fixed-rate emerging markets are also insignificant.

Table 5: Simple Hypothesis Test Results

\begin{tabular}{|c|c|c|c|c|c|c|c|}
\hline \multicolumn{8}{|c|}{$\begin{array}{l}\text { Simple Hypothesis Test } \\
H_{0} \text { : The average } H / L \text { carry trade return during periods of high volatility innovations = } \\
0\end{array}$} \\
\hline & & \multicolumn{2}{|c|}{ G10 and 8 Free-Float } & \multicolumn{2}{|c|}{$\begin{array}{c}\text { G10 and } 10 \\
\text { Managed-Float }\end{array}$} & \multicolumn{2}{|c|}{ G10 and 10 Fixed-Rate } \\
\hline & & $\begin{array}{l}\text { High } \\
\Delta \text { VOL }\end{array}$ & $\begin{array}{c}\text { High } \\
\text { G10 } \\
\Delta \text { VOL }\end{array}$ & $\begin{array}{c}\text { High } \\
\Delta \text { VOL }\end{array}$ & $\begin{array}{c}\text { High } \\
\text { G10 } \\
\Delta \text { VOL }\end{array}$ & $\begin{array}{l}\text { High } \\
\Delta \text { VOL }\end{array}$ & $\begin{array}{l}\text { High G10 } \\
\quad \Delta \text { VOL }\end{array}$ \\
\hline \multirow{3}{*}{$\begin{array}{c}\text { Top } \\
1 / 4 \\
\text { quintile }\end{array}$} & Mean & $-16.02 \%$ & $-11.19 \%$ & $0.70 \%$ & $-0.94 \%$ & $-1.43 \%$ & $-2.36 \%$ \\
\hline & $\mathrm{t}$ & -2.557 & -2.246 & 0.181 & -0.247 & -0.148 & -0.070 \\
\hline & p-value & 0.014 & 0.029 & 0.858 & 0.806 & 0.883 & 0.944 \\
\hline \multirow{3}{*}{$\begin{array}{l}\text { Top } \\
1 / 5 \\
\text { quintile }\end{array}$} & Mean & $-15.56 \%$ & $-12.62 \%$ & $-1.00 \%$ & $-1.90 \%$ & $-2.67 \%$ & $-1.90 \%$ \\
\hline & $\mathrm{t}$ & -2.279 & -2.134 & -0.219 & -0.410 & -0.059 & -0.182 \\
\hline & $\mathrm{p}$-value & 0.028 & 0.039 & 0.828 & 0.684 & 0.953 & 0.856 \\
\hline \multirow{3}{*}{$\begin{array}{c}\text { Top } \\
1 / 6 \\
\text { quintile }\end{array}$} & Mean & $-18.05 \%$ & $-15.68 \%$ & $-5.30 \%$ & $-2.13 \%$ & $-5.94 \%$ & $-0.60 \%$ \\
\hline & $\mathrm{t}$ & -2.426 & -2.322 & -1.149 & -0.408 & -0.666 & -0.272 \\
\hline & $\mathrm{p}$-value & 0.021 & 0.027 & 0.259 & 0.686 & 0.510 & 0.787 \\
\hline \multirow{3}{*}{$\begin{array}{c}\text { Top } \\
1 / 7 \\
\text { quintile }\end{array}$} & Mean & $-18.79 \%$ & $-12.98 \%$ & $-8.06 \%$ & $-3.74 \%$ & $-5.81 \%$ & $-3.00 \%$ \\
\hline & $\mathrm{t}$ & -2.165 & -1.784 & -1.571 & -0.618 & -0.178 & -0.830 \\
\hline & $\mathrm{p}$-value & 0.039 & 0.085 & 0.128 & 0.542 & 0.860 & 0.414 \\
\hline \multirow{3}{*}{$\begin{array}{c}\text { Top } \\
\text { 1/8 } \\
\text { quintile }\end{array}$} & Mean & $-19.72 \%$ & $-11.88 \%$ & $-7.18 \%$ & $-2.61 \%$ & $-6.04 \%$ & $-1.31 \%$ \\
\hline & $\mathrm{t}$ & -2.209 & -1.483 & -1.332 & -0.389 & -0.564 & -0.568 \\
\hline & $\mathrm{p}$-value & 0.037 & 0.151 & 0.195 & 0.700 & 0.578 & 0.575 \\
\hline
\end{tabular}

Table 5 reports the simple hypothesis test results of mean returns on the $\mathrm{H} / \mathrm{L}$ carry trade portfolio for free-float, managed-float, and fixed-rate carry trades during periods of high volatility innovations. The null hypothesis is that the average H/L 
carry trade return during periods of high volatility innovations is zero. The rows "Top 1/4 quintile," "Top 1/5 quintile," "Top 1/6 quintile," "Top 1/7 quintile," and "Top 1/8 quintile" show, respectively, the mean of the highest $1 / 4,1 / 5,1 / 6,1 / 7$, and $1 / 8$ quintile of the $\mathrm{H} / \mathrm{L}$ carry trade portfolio returns on free-float, managed-float, and fixed-rate carry trade sorted separately by their sample volatility innovations (High $\triangle$ VOL) and by G10 volatility innovations (High G10 $\Delta$ VOL). T statistics and P-values are also reported. The sample period is from March 2000 to February 2017. Monthly transaction cost adjusted returns are used. All returns are annualized.

Table 6 compares the returns and components of the free-float, managed-float, and fixed-rate carry trades for the results in Figure 4, including the average H/L carry trade return, average return on Portfolio 5, average return on Portfolio 1, average interest rate difference between Portfolio 5 and the US, average interest rate difference between Portfolio 1 and the US, and the average transaction costs during periods of high or low sample or G10 volatility innovations. The table also reports the average return differences between the managed- and free-float carry trades with one-sided p-values in parenthesis. All returns and costs are annualized.

One interesting result in Table 6 is the contrast between the free-float carry trade and the manage-float carry trade during periods of high G10 volatility innovations. The average $\mathrm{H} / \mathrm{L}$ carry trade return difference is $10.25 \%$ on an annual basis. The corresponding average returns on funding currencies (Portfolio 1), the average interest rate difference between Portfolio 5 and the US, the average interest rate difference between Portfolio 1 and the US, the average transaction costs are all close to each other. The real difference is the average return on investment currencies (Portfolio 5). The average return on Portfolio 5 of the G10 and 8 free-float emerging markets is $-24.18 \%$, indicating that, on average, the investment currencies (usually free-float emerging markets) depreciate 24.18 percent against the USD during periods of high G10 volatility innovations. However, the average return on Portfolio 5 of the G10 and 10 managed-float emerging markets is only $-15.83 \%$, indicating that, on average, the investment currencies (usually managed-float emerging markets) depreciate by 15.83 percent against the USD during periods of high G10 volatility innovations. The investment currencies of managed-float carry trade depreciate much less than that of free-float carry trade in periods of high G10 volatility innovations.

Similarly, Table 6 also shows that in periods of low sample volatility innovations, the investment currencies of free-float carry trade appreciate much more than those of the managed-float or fixed-rate carry trades, leading to higher carry trade returns. In addition to testing the subsample of G10 and 28 emerging markets, I also test the whole sample for robustness. I divide the 40 emerging markets into groups of 8 freefloat, 17 managed-float, and 15 fixed-rate regimes, though some countries such as Hungary are not suitable to categorize into a single currency regime from 2000 to 2017. I combine each group with all 22 developed economies and G10 economies separately. The empirical results are similar. From the top $1 / 4$ quintile to the top $1 / 8$ quintile sorted by volatility innovations, the free-float carry trade returns are highly 
significantly negative. The corresponding p-values are $1.5 \%, 0.2 \%, 0.4 \%, 1.7 \%$, and $2.3 \%$ under the sample volatility innovations and $3.1 \%, 3.3 \%, 2.0 \%, 5.5 \%$, and $7.1 \%$ under G10 volatility innovations. The results for the managed-float and fixedrate carry trades are almost insignificant. 
Table 6: Components of Carry Trade Returns

\begin{tabular}{|c|c|c|c|c|c|c|c|c|c|c|c|c|}
\hline & \multicolumn{3}{|c|}{ Low G10 Volatility Innovations } & \multicolumn{3}{|c|}{$\begin{array}{c}\text { Low Sample Volatility } \\
\text { Innovations }\end{array}$} & \multicolumn{3}{|c|}{$\begin{array}{l}\text { High G10 Volatility } \\
\text { Innovations }\end{array}$} & \multicolumn{3}{|c|}{$\begin{array}{c}\text { High Sample Volatility } \\
\text { Innovations }\end{array}$} \\
\hline & $\begin{array}{l}\text { Free- } \\
\text { Float }\end{array}$ & $\begin{array}{l}\text { Managed- } \\
\text { Float }\end{array}$ & $\begin{array}{l}\text { Fixed- } \\
\text { Rate }\end{array}$ & $\begin{array}{l}\text { Free- } \\
\text { Float }\end{array}$ & $\begin{array}{l}\text { Managed- } \\
\text { Float }\end{array}$ & $\begin{array}{l}\text { Fixed- } \\
\text { Rate }\end{array}$ & $\begin{array}{l}\text { Free- } \\
\text { Float }\end{array}$ & $\begin{array}{l}\text { Managed- } \\
\text { Float }\end{array}$ & $\begin{array}{l}\text { Fixed- } \\
\text { Rate }\end{array}$ & $\begin{array}{l}\text { Free- } \\
\text { Float }\end{array}$ & $\begin{array}{l}\text { Managed- } \\
\text { Float }\end{array}$ & $\begin{array}{l}\text { Fixed-- } \\
\text { Rate }\end{array}$ \\
\hline $\begin{array}{l}\text { Average } \mathrm{H} / \mathrm{L} \text { carry trade } \\
\text { return }\end{array}$ & $17.62 \%$ & $20.70 \%$ & $12.03 \%$ & $26.69 \%$ & $19.54 \%$ & $10.71 \%$ & $-11.19 \%$ & $-0.94 \%$ & $-2.36 \%$ & $-16.02 \%$ & $0.70 \%$ & $-1.43 \%$ \\
\hline $\begin{array}{l}\text { Average return on Portfolio } 5 \\
\text { (investment currencies) }\end{array}$ & $0.59 \%$ & $0.96 \%$ & $0.07 \%$ & $12.37 \%$ & $3.19 \%$ & $-1.12 \%$ & $-24.18 \%$ & $-15.83 \%$ & $-4.16 \%$ & $-29.28 \%$ & $-15.53 \%$ & $-7.88 \%$ \\
\hline $\begin{array}{l}\text { Average return on Portfolio } 1 \\
\text { (funding currencies) }\end{array}$ & $-6.02 \%$ & $-5.66 \%$ & $-5.39 \%$ & $-2.87 \%$ & $-2.28 \%$ & $-5.20 \%$ & $-2.15 \%$ & $-2.60 \%$ & $-1.80 \%$ & $-2.40 \%$ & $-3.99 \%$ & $-0.34 \%$ \\
\hline $\begin{array}{l}\text { Average interest rate } \\
\text { difference b/w Portfolio } 5 \text { and } \\
\text { USD }\end{array}$ & $10.13 \%$ & $13.05 \%$ & $5.51 \%$ & $10.81 \%$ & $12.99 \%$ & $5.54 \%$ & $10.38 \%$ & $11.21 \%$ & $4.97 \%$ & $10.40 \%$ & $11.17 \%$ & $5.11 \%$ \\
\hline $\begin{array}{l}\text { Average interest rate } \\
\text { difference b/w Portfolio } 1 \text { and } \\
\text { USD }\end{array}$ & $-1.13 \%$ & $-1.41 \%$ & $-1.31 \%$ & $-1.00 \%$ & $-1.45 \%$ & $-1.33 \%$ & $-0.69 \%$ & $-1.38 \%$ & $-1.25 \%$ & $-0.66 \%$ & $-1.35 \%$ & $-1.30 \%$ \\
\hline Average transaction costs & $0.25 \%$ & $0.38 \%$ & $0.24 \%$ & $0.35 \%$ & $0.37 \%$ & $0.24 \%$ & $0.23 \%$ & $0.31 \%$ & $0.16 \%$ & $0.19 \%$ & $0.28 \%$ & $0.31 \%$ \\
\hline $\begin{array}{l}\text { Average return difference } \\
\text { (with one-sided p-value) b/w } \\
\text { managed-float and free-float } \\
\text { carry trade }\end{array}$ & \multicolumn{3}{|c|}{$3.08 \%(29.1 \%)$} & \multicolumn{3}{|c|}{$-7.15 \%(12.0 \%)$} & \multicolumn{3}{|c|}{$10.25 \%(5.3 \%)$} & \multicolumn{3}{|c|}{$16.72 \%(1.3 \%)$} \\
\hline
\end{tabular}


Table 6 reports the components of carry trade returns on Group Low (low sample/G10 volatility innovations) and Group High (high sample/G10 volatility innovations) in Figure 4. The components of the average H/L carry trade return include the average return on Portfolio 5, average return on Portfolio 1, average interest rate difference between Portfolio 5 and USD, average interest rate difference between Portfolio 1 and USD, and average transaction costs of free-float, managed-float and fixed-rate carry trades. The average return differences between managed-float and free-float carry trade (with one-sided p-values in parenthesis) are also reported. All returns and costs are annualized. The sample period is from March 2000 to February 2017.

I also use the Morgan Stanley Capital International (MSCI) Index volatility innovations measure proposed by Lustig et al. (2011) as a substitute for the global FX volatility innovations. I download $35 \mathrm{MSCI}$ country indexes in local currencies from Reuters (DataStream). However, under the Lustig measure, all returns are insignificant. This result indicates that Lustig's stock volatility innovations measure does not work well in currency markets. Table A1 in Appendix A presents the hypothesis test results for the MSCI volatility innovations measure.

As we can see from the figures and tables in this section, the country-specific factors are diversified away at the portfolio level. The real, non-diversifiable difference between the currencies of the free-float and managed-float emerging markets is the existence of government currency controls and currency interventions in the latter case. I will focus on government currency intervention in the next section.

\subsection{Government currency intervention in emerging markets as an explanation of carry trade return differences}

Government or central bank currency intervention in emerging markets can explain the differences in returns between the free-float and managed-float carry trades during periods of high volatility innovations. In times of high volatility innovations, investment currencies tend to depreciate. Governments intervene in foreign exchange markets with their currency reserves to support the local currency, slowing down the depreciation process. Therefore, given the same period, managedfloat investment currencies depreciate less than what they would if they were freefloating, leading to higher carry trade returns. From the investors' perspective, they sell the local currency for USD at a higher price than if the currency were to free float. This can be thought as a free put option given to investors. By buying the excess amount of dollars provided through the central bank's currency intervention, investors are actually exercising the currency put options.

Government currency intervention can also occur during periods of currency appreciation. Similarly, the government intervenes to stem the rise of the local currency and accumulates FX reserves by issuing local currencies and buying excess market dollars. Therefore, given the same period, managed-float investment currencies appreciate less than what they would if they were free float. From the investors' perspective, they push the local currency price up lower than if the currency were free float. This can also be thought as a free call option given to the 
government. By printing local currencies and buying USD, the government is actually exercising the currency call options.

Government currency interventions prevail in fixed-rate regimes as well, and a similar analysis applies.

Combined together, there is an option value in government currency intervention, consisting of a combination of short currency call options and long put options from the investors' prospective. We can measure the differences in the carry trade returns between the regimes using these options. The call option becomes valuable as the local currency tends to appreciate, indicating that the central bank in a managedfloat or fixed-rate regime must buy the excess USD to slow the appreciation of local currency down. The put option becomes valuable as the local currency tends to depreciate, indicating that central banks in a managed-float or fixed-rate regime must meet the excess market demand for USD by selling its FX reserves to slow the depreciation of the local currency down. As volatility increases, both call and put options are valuable, indicating that the government or central bank must intervene constantly in the currency markets to keep the price of the local currency within a given band.

It is worth noting that there is an interesting trade-off faced by investors in the presence of government intervention: carry trade investing in emerging (managed) currencies lose less when volatility innovation is high, but also gain less when volatility innovation is low. The net effect on the carry trade is lower volatility but the effect on the mean is ambiguous. It depends on the relative valuation of long put vs. short call options imbedded in government intervention.

\subsection{An indirect evidence of government currency intervention in carry trade}

Although I do not have specific data or records on how central banks intervene in currency markets, I present an indirect evidence that government currency intervention causes the return differences between different types of carry trades. I use countries in the monitoring list proposed by Macroeconomic and Foreign Exchange Policies of Major Trading Partners of the United States from 2016 to 2019. The reports are prepared semi-annually by U.S. Department of Treasury to U.S. Congress. I include all the authorities in the lists since they vary year by year. These authorities are: China, Japan, Korea, Taiwan, Germany, Switzerland, India, Italy, Ireland, Singapore, Malaysia and Vietnam. Germany, Italy and Ireland are in the Euro area. Japan and Switzerland are also part of G10 countries. The reports specifically and extensively state that China, Korea, Taiwan, India, Singapore, Malaysia and Vietnam use FX intervention, denoted as the intervention economies. I combine their currencies with G10 currencies and re-do the analysis.

Figure 5 shows the result. I provide a simple graphical illustration of the relationship between the carry trade returns and volatility innovations. The illustration consists of carry trade returns for the G10 countries and 7 intervention economies (the intervention carry trade). Similar to previous figures, I divide the average H/L carry trade returns into four groups. The first group contains the 25 percent of the months 
of carry trade returns with the lowest values of their sample volatility innovations. The fourth group contains the 25 percent of the months of carry trade returns with the highest values of their sample volatility innovations. The second and third group each contains the 25 percent of the months in between. Then, I take the average carry trade returns within each group. I also sort the months by G10 volatility innovations for comparison.

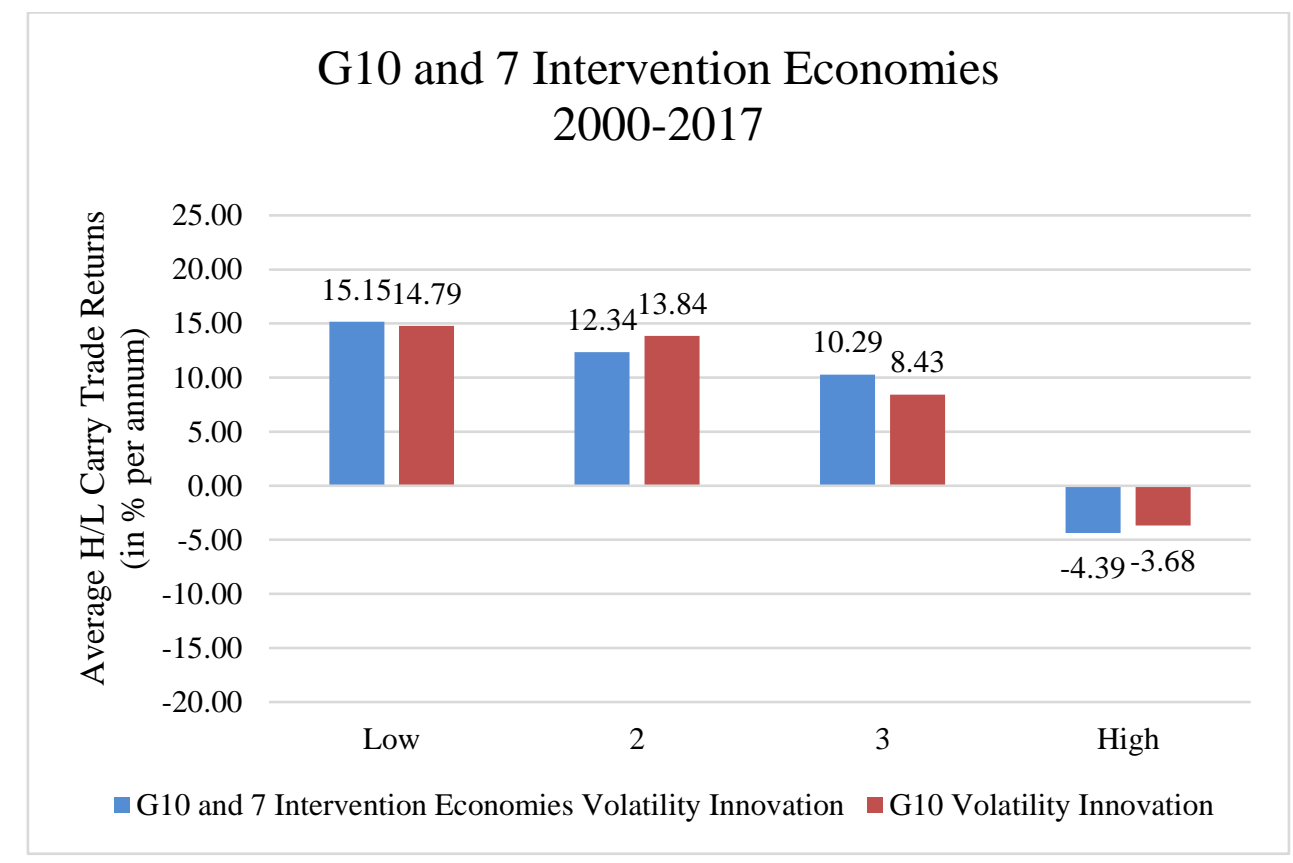

Figure 5: Carry Trade Returns and Volatility with Intervention Economies

Figure 5 shows the mean annualized H/L carry trade portfolio returns for G10 and 7 Intervention Economies conditional on volatility innovations sorted by the lowest 25 percent quintile to the highest 25 percent quintile (four categories from "Low" to High" on the x-axis). The H/L carry trade portfolio goes long on Portfolio 5 (highest forward discount) and short on Portfolio 1 (lowest forward discount). The figure shows the results for the G10 countries and 7 Intervention Economies. The blue bars indicate the mean carry trade returns conditional on the sample volatility innovations. The red bars represent the mean carry trade returns conditional on G10 volatility innovations. The G10 countries are the Euro area, Japan, the United Kingdom, Australia, Canada, Switzerland, Sweden, New Zealand, Norway, and Denmark. The 7 intervention economies are China, Korea, Taiwan, India, Singapore, Malaysia and Vietnam. USD is the base currency. The sample period is from March 2000 to February 2017.

Figure 5 shows that the monotonic relations between carry trade returns and volatility innovations still holds for G10 and 7 intervention economies. As volatility innovations increase, carry trade returns decrease. However, during periods of high 
volatility innovations, the intervention carry trade returns outperform that of freefloat carry trade but seem ambiguous compared to managed-float or fixed-rate carry trade in Figure 4. Table 7 test the return differences more rigorously.

Table 7 shows the two-sample heteroscedastic hypothesis test for the differences between the average carry trade returns. The null hypothesis is that the average H/L carry trade return difference between the free-float/managed-float/fixed-rate carry trade and the intervention carry trade is greater than zero during periods of high volatility innovations. The row "Top 1/4 quintile," "Top $1 / 5$ quintile," "Top 1/6 quintile," "Top $1 / 7$ quintile," and "Top $1 / 8$ quintile" show, respectively, the mean difference of the highest $1 / 4,1 / 5,1 / 6,1 / 7$, and 1/8 quintiles between free-float and the intervention, between managed-float and the intervention, and between fixedrate and the intervention carry trade portfolio returns sorted separately by their sample volatility innovations (High $\triangle \mathrm{VOL}$ ) and by G10 volatility innovations (High G10 $\Delta$ VOL). All returns are annualized. 
Table 7: Two-Sample Heteroscedastic Hypothesis Test Results

\begin{tabular}{|c|c|c|c|c|c|c|c|}
\hline \multicolumn{8}{|c|}{$\begin{array}{l}\text { Two-sample Heteroscedastic Hypothesis Test for Average } H / L \text { Carry Trade } \\
\text { Return differences during periods of high volatility innovations } \\
\text { Ho: The average } H / L \text { carry trade return difference during periods of high } \\
\text { volatility innovations }>0\end{array}$} \\
\hline & & \multicolumn{2}{|c|}{$\begin{array}{c}\text { Free-Float - } \\
\text { Intervention Carry } \\
\text { Trade }\end{array}$} & \multicolumn{2}{|c|}{$\begin{array}{c}\text { Managed-Float - } \\
\text { Intervention Carry } \\
\text { Trade }\end{array}$} & \multicolumn{2}{|c|}{$\begin{array}{l}\text { Fixed-Rate - } \\
\text { Intervention } \\
\text { Carry Trade } \\
\end{array}$} \\
\hline & & $\begin{array}{c}\text { High } \\
\Delta \mathrm{VOL}\end{array}$ & $\begin{array}{c}\text { High } \\
\text { G10 } \\
\Delta \mathrm{VOL} \\
\end{array}$ & $\begin{array}{c}\text { High } \\
\Delta \mathrm{VOL}\end{array}$ & $\begin{array}{l}\text { High } \\
\text { G10 } \\
\Delta \mathrm{VOL}\end{array}$ & $\begin{array}{c}\text { High } \\
\Delta \mathrm{VOL}\end{array}$ & $\begin{array}{c}\text { High } \\
\text { G10 } \\
\Delta \mathrm{VOL} \\
\end{array}$ \\
\hline \multirow{3}{*}{$\begin{array}{c}\text { Top } \\
1 / 4 \\
\text { quintile }\end{array}$} & Mean & $-11.6 \%$ & $-7.5 \%$ & $0.1 \%$ & $2.7 \%$ & $-3.6 \%$ & $1.9 \%$ \\
\hline & $\mathrm{t}$ & -1.650 & -1.272 & 1.006 & 0.551 & -0.584 & 0.342 \\
\hline & p-value & 0.052 & 0.103 & 0.159 & 0.291 & 0.280 & 0.367 \\
\hline \multirow{3}{*}{$\begin{array}{c}\text { Top } \\
1 / 5 \\
\text { quintile }\end{array}$} & Mean & $-9.2 \%$ & $-6.6 \%$ & $5.3 \%$ & $4.2 \%$ & $-4.7 \%$ & $5.5 \%$ \\
\hline & $\mathrm{t}$ & -1.175 & -0.940 & 0.896 & 0.700 & -0.622 & 0.878 \\
\hline & p-value & 0.122 & 0.175 & 0.187 & 0.243 & 0.268 & 0.191 \\
\hline \multirow{3}{*}{$\begin{array}{c}\text { Top } \\
1 / 6 \\
\text { quintile }\end{array}$} & Mean & $-12.6 \%$ & $-9.1 \%$ & $0.2 \%$ & $4.5 \%$ & $-9.8 \%$ & $8.9 \%$ \\
\hline & $\mathrm{t}$ & -1.452 & -1.130 & 0.027 & 0.660 & -1.125 & 1.266 \\
\hline & $\mathrm{p}$-value & 0.076 & 0.132 & 0.489 & 0.256 & 0.133 & 0.105 \\
\hline \multicolumn{8}{|c|}{ Table 7 Continued } \\
\hline \multirow{3}{*}{$\begin{array}{c}\text { Top } \\
1 / 7 \\
\text { quintile }\end{array}$} & Mean & $-13.0 \%$ & $-4.8 \%$ & $-2.3 \%$ & $4.5 \%$ & $-10.3 \%$ & $8.5 \%$ \\
\hline & $\mathrm{t}$ & -1.302 & -0.543 & -0.321 & 0.568 & -1.042 & 1.055 \\
\hline & p-value & 0.100 & 0.295 & 0.375 & 0.286 & 0.152 & 0.148 \\
\hline \multirow{3}{*}{$\begin{array}{c}\text { Top } \\
1 / 8 \\
\text { quintile }\end{array}$} & Mean & $-12.1 \%$ & $-4.8 \%$ & $0.4 \%$ & $4.5 \%$ & $-8.4 \%$ & $9.5 \%$ \\
\hline & $\mathrm{t}$ & -1.161 & -0.492 & 0.057 & 0.524 & -0.770 & 1.087 \\
\hline & p-value & 0.126 & 0.313 & 0.477 & 0.301 & 0.223 & 0.141 \\
\hline
\end{tabular}

Table 7 reports the two-sample heteroscedastic hypothesis test for the differences of the average carry trade returns during periods of high volatility innovations. The null hypothesis is that the average $\mathrm{H} / \mathrm{L}$ carry trade return difference between the free-float/managed-float/fixed-rate carry trade and the intervention carry trade is greater than zero during periods of high volatility innovations. The row "Top $1 / 4$ quintile," "Top 1/5 quintile," "Top 1/6 quintile," “Top 1/7 quintile," and "Top 1/8 quintile" show, respectively, the mean differences of the highest 1/4, 1/5, 1/6, 1/7, and $1 / 8$ quintiles between the free-float and the intervention, between the managedfloat and the intervention, and between the fixed-rate and the intervention carry trade sorted separately by their sample volatility innovations (High $\triangle$ VOL) and by G10 volatility innovations (High G10 $\Delta$ VOL). One-sided T statistics and P-values are also reported. The sample period is from March 2000 to February 2017. Monthly 
transaction cost adjusted returns are used. All returns are annualized.

As we can see from Table 7 , the average $\mathrm{H} / \mathrm{L}$ return differences between free-float and intervention carry trades during periods of high sample volatility innovations are significantly negative. The significance levels decline with high G10 volatility innovations. However, the average $\mathrm{H} / \mathrm{L}$ return differences between managed-float and the intervention carry trades during periods of high volatility innovations are insignificant. The average $\mathrm{H} / \mathrm{L}$ carry trade return differences between fixed-rate and the intervention carry trades are mostly insignificant, with only a few close to $90 \%$ significance.

In sum, the intervention carry trade returns significantly outperform that of freefloat carry trade in periods of high volatility innovations, while the mean differences between managed-float/fixed-rate and intervention carry trade portfolio returns are ambiguous. This indicate that during periods of high volatility innovations when currency intervention usually happens, the average returns of the intervention and managed-float carry trade are similar, while they are significantly higher than freefloat carry trade. This indirect evidence supports my argument that government currency intervention causes the return differences between free-float and managedfloat carry trades in periods of high volatility innovations.

The following section proposes an American currency option model with stochastic strikes to calculate the put and call option values of government currency intervention.

\section{The Option Value of Government Currency Intervention}

In the previous section, I point out that there is an option value in government currency intervention; that is, a combination of call and put options. The call options are valuable if the currency tends to appreciate and the put options are valuable if the currency tends to depreciate. In this section, I propose an American currency put option model with stochastic strikes to describe and calculate the put option value in government currency intervention during periods of high volatility innovations, when high interest currencies tend to depreciate. Similarly, I propose an American currency call option model with stochastic strikes to describe and calculate the call option value in government currency intervention during periods of low volatility innovations when high interest currencies tend to appreciate.

\subsection{American currency put and call option model with stochastic strikes}

This section describes the American currency put and call option model with stochastic strikes.

For the put option, suppose that for a managed-float developing country A (or a portfolio of managed-float developing countries), the average exchange rate during periods of high volatility innovations if it were free float is $S$.

Country A's FX reserve consists of only USD and the amount of the reserve is $Q$. 
The central bank of country A has a currency intervention scheme $\left(K_{l}, Q_{1}\right),\left(K_{2}\right.$, $Q_{2}$ ), ... , $\left(K_{n}, Q_{n}\right.$ ) (where $\left.K_{i}>K_{i+1}\right)$. At each exchange rate level $K_{i}$, the maximum amount that the central bank would spend to meet excess market demand for USD to defend its currency from depreciation is $Q_{i}$. If the market demand for USD is more than $Q_{i}$, then the exchange rate will fall to $K_{i+1}$. The following relation holds for $Q_{i}$ :

$$
\sum_{i=1}^{n} Q_{i}=Q
$$

Then, the weighted average price of intervention is

$$
\bar{K}=\frac{1}{Q} \sum_{i=1}^{n} K_{i} Q_{i}=\sum_{i=1}^{n} K_{i} \frac{Q_{i}}{Q}=\sum_{i=1}^{n} K_{i} w_{i},
$$

where,

$$
\begin{array}{r}
w_{i}=\frac{Q_{i}}{Q} \\
\sum_{i=1}^{n} w_{i}=1
\end{array}
$$

Since $w_{i}(i=1, \ldots, n)$ are weights between 0 to 1 and all $w_{i}$ sum to one, we can treat $w_{i}$ as the probability. Therefore, we can think of $K$ as stochastically distributed with some probability measure $P$. As $n$ goes to infinity, on a continuous basis, we can write the expected $K$ as

$$
E(K)=\sum_{i=-\infty}^{+\infty} K_{i} w_{i}=\int_{-\infty}^{+\infty} K \phi(p) d p
$$

where $\phi(p)$ is the probability density function of $K$.

Since we look only at the periods of high volatility innovations when the local currency depreciates, we can view the whole foreign exchange reserve with an intervention scheme as a portfolio of put options with a stochastically distributed strike price of $\widetilde{K}$. It is an American option since the exercise time is any time during the trading days. For every USD of central bank intervention, the investor exercises a stochastic strike American currency put option. Suppose that $V_{i}$ is the price of American currency put option at strike price $K_{i}$; then, we can calculate $V_{i}$ by the Least Squares Monte Carlo (LSM) proposed by Longstaff and Schwartz (2001), expressed as

$$
V_{i}=L S M_{P u t}\left(K_{i}, S, r_{f}, r_{d}, T, \sigma\right)
$$

where $K_{i}$ is the strike price. $S$ is the exchange rate if it were a free-float regime. The prices are presented as the amount of USD for a unit of local currency. $T$ is the time to maturity. $r_{d}$ is the U.S. interest rate and $r_{f}$ is the local currency's interest rate. $\sigma$ is the free-float exchange rate volatility.

The value of the American currency put option with discreet stochastic strikes is

$$
P u t=E(V)=\sum_{i=1}^{n} V_{i} \frac{Q_{i}}{Q}
$$


For continuous strikes, the put option value becomes

The case for the American currency call option model with stochastic strikes is similar. The only difference is the intervention scheme, in which the local government or central bank intervenes to stem the rise of local currencies. For every

$$
P u t=\int_{-\infty}^{+\infty} V\left(K, S, r_{f}, r_{d}, T, \sigma\right) \phi(p) d p
$$

USD of central bank intervention, the government exercises a stochastic strike American currency call option, which we can also calculate using the LSM method: Therefore, the value of American currency call option with discreet stochastic

$$
V_{i}=L S M_{\text {Call }}\left(K_{i}, S, r_{f}, r_{d}, T, \sigma\right)
$$

strikes is

$$
\text { Call }=E(V)=\sum_{i=1}^{n} V_{i} \frac{Q_{i}}{Q}
$$

For continuous strikes, the call option value becomes

$$
\text { Call }=\int_{-\infty}^{+\infty} V\left(K, S, r_{f}, r_{d}, T, \sigma\right) \phi(p) d p
$$

\subsection{Numerical calculation of the value of the put option of government currency intervention}

Since there is no explicit solution to the American currency put option with stochastic strikes, I use Monte Carlo methods to calculate the put option value in government currency intervention. I create 1,000 random strike prices with a probability distribution (e.g., normal distribution). For each strike price, I modify the LSM proposed by Longstaff and Schwartz (2001) to a currency version and calculate $V_{i}$, which is the price of a put option with strike price $K_{i}$. Then, I take the average over all $V_{i}$ to obtain the value of the American currency put option with stochastic strikes. In periods of high volatility innovations, put options are valuable.

I make several assumptions about the option parameters:

(i) The initial standardized exchange rate of Portfolio 5 is 1.

(ii) $T=1 / 12$. The option's time to maturity is one month.

(iii) $r_{d}=1.680 \%$. From Reuters Datastream, during the months of high G10

volatility innovations over the sample period, the average month-end U.S. 3month repo rate is $1.680 \%$. Here, USD is the base currency. The rate is annualized.

(iv) $r_{f}=7.717 \%$. From Reuters Datastream, I take the average of month-end 3month rates available of the 8 managed-float currencies in periods of high G10 volatility innovations. The 8 managed-float interest rates are China Interbank 3M Shanghai, Russian Ruble 3-Month Deposit, India T-Bill 3 Month, Thailand Interbank 3M Bangkok, Malaysia Interbank 3-Month, Romania Interbank 3M, Colombia CD Rate 90-Day, and Argentina LEBAC 
Rate 3 Months. All rates are the middle rate or the only rate available on Reuters Datastream. All rates are annualized.

(v) $\sigma=13.24 \%$. This is the free-float volatility, which is the average volatility of the G10 and 8 free-float Portfolio 5 during periods of high G10 volatility innovations. The number is annualized.

(vi) $S$ is the hypothetical free-float exchange rate if the managed-float currencies became free-float during periods of high G10 volatility innovations. It is hard to estimate the true "free-float" exchange rate for a single managed-float currency. However, on the portfolio level, the exchange rate behavior of a free-float carry trade portfolio can be a reasonable substitute. From Table 6, we know that during periods of high G10 volatility innovations, the average depreciation of the G10 and 8 free-float carry trade Portfolio 5 is $24.18 \%$ against USD. With an assumed initial exchange rate of 1 , the average freefloat exchange rate is $1-0.2418=0.7582$. In addition, note that in assumption (v), the free-float volatility is $\sigma=13.24 \%$. Therefore, we can fairly assume that $\mathrm{S}$ follows a normal distribution with mean $\mu_{s}=0.7582$ and standard deviation $\sigma=13.24 \%$.

(vii) $K \sim N\left(\mu, \sigma_{K}^{2}\right)$. The strike price follows a normal distribution with mean $\mu$ and standard deviation $\sigma_{K}$.

(viii) $\mu=0.8417$. From Table 6 , the average depreciation of the G10 and 10 managed-float carry trade Portfolio 5 is 15.83 percent against USD during periods of high G10 volatility innovations. Therefore, the mean strike price is $\mu=1-0.1583=0.8417$.

(ix) $\sigma_{K}=10 \%$. I choose this value arbitrarily to indicate that most of the central bank's intervention occurs between within an up and down 10 percent band of the mean strike price $\mu$.

With these assumptions, I generate 1,000 hypothetical free-float exchange rates $S$ randomly with the normal distribution described in assumption (vi) and calculate the option value for each $S$. In the LSM simulation, I use 1,000 random normal strikes, 1,000 time-steps, and 6,000 time paths. For each $S$, I calculate the option price 6 times and take the median value as its option price. Then, I sort these 1,000 stochastic strike American put option prices from low to high and report the 5\%, $50 \%$, and $95 \%$ percentiles. Table 8 presents the results. Note that in Table 6 , the average $\mathrm{H} / \mathrm{L}$ carry trade return difference between the managed- and free-float regimes is $10.25 \%$ during periods of high G10 volatility innovations. The difference in returns is close to the $50 \%$ percentile of the put option price.

Although the average call option is considered worthless in this setup, I also calculate its value for comparison. All parameters are the same with the put option, and $\mathrm{I}$ also report these results in Table 8 . The call option is very small for the $5 \%$ and $50 \%$ percentile, but can become valuable in extreme cases ( $95 \%$ percentile). 
Table 8: Numerical Results

\begin{tabular}{|c|c|c|c|c|}
\hline \multirow{2}{*}{$\begin{array}{c}\text { High G10 } \\
\Delta \text { VOL }\end{array}$} & Put option price & $0.61 \%$ & $9.94 \%$ & $30.77 \%$ \\
\cline { 2 - 5 } & Call option price & $0.00 \%$ & $1.37 \%$ & $15.32 \%$ \\
\hline \multirow{2}{*}{ Low $\Delta$ VOL } & Call option price & $0.08 \%$ & $7.28 \%$ & $23.35 \%$ \\
\cline { 2 - 5 } & Put option price & $0.00 \%$ & $0.41 \%$ & $11.36 \%$ \\
\hline
\end{tabular}

Table 8 reports the numerical results for the prices of American put and call options with stochastic strikes in periods of high G10 volatility innovations (high G10 $\triangle \mathrm{VOL}$ ) and low sample volatility innovations (low $\Delta \mathrm{VOL}$ ). The parameters of the put and call option prices for high G10 $\Delta$ VOL are presented in Section 5.2. The parameters of the put and call options for low $\triangle$ VOL are presented in Section 5.3. The results are reported in percentiles based on 1,000 sets of simulated data. In the calculation, 1,000 hypothetical free-float exchange rates are generated randomly using a normal distribution with parameters specified in assumption (vi) in Section 5.2 and Section 5.3 separately. In the Monte Carlo simulation, 1,000 random normal strikes, 1,000 time-steps, and 6,000 time paths are used. All option prices are calculated 6 times and the median is used as its final value.

\subsection{Numerical calculation of the value of the call option of government currency intervention}

Similar to Section 5.2, in periods of low sample volatility innovations, call options are valuable. The assumptions are as follows:

(i) The initial standardized exchange rate of Portfolio 5 is 1.

(ii) $T=1 / 12$, as in Section 5.2 (ii).

(iii) $r_{d}=1.582 \%$. During the months of low G10 and 10 managed-float volatility innovations over the sample period, the average month-end US 3-month repo rate is $1.582 \%$. Here, USD is the base currency. The rate is annualized.

(iv) $r_{f}=7.759 \%$. I take the average of month-end 3-month rates available for the 8 managed-float currencies in Section 5.2 (iv) during periods of low G10 and 10 managed-float volatility innovations. All rates are annualized.

(v) $\sigma=10.28 \%$. This is the free-float volatility, which is the average volatility of the G10 and 8 free-float Portfolio 5 during periods of low volatility innovations of the G10 and 10 managed-float sample. In addition, note that the average volatility of the G10 and 8 free-float Portfolio 5 in periods of low sample volatility innovations is $10.27 \%$. The volatility difference is very small. All numbers are annualized.

(vi) Similar to Section 5.2 (vi), $S$ is the hypothetical free-float exchange rate if the managed-float currencies became free-floating during periods of low G10 and 
10 managed-float volatility innovations. From Table 6, during periods of low G10 and 10 managed-float volatility innovations, the G10 and 8 free-float carry trade Portfolio 5 appreciates 12.37 percent against USD on average and its average interest rate over the US is 2.18 percent $(12.99 \%-10.81 \%=$ $2.18 \%)$ lower than that of the G10 and 10 managed-float. With an assumed initial exchange rate of 1 , the current average free-float exchange rate is $1+$ $0.1237-0.0218=1.1019$. Note that I must subtract the interest rate difference $(2.18 \%)$ since the free-float currency and the hypothetical "free-float" managed-float currency are actually the "same" currency, only with different interest rates. In this case, uncovered interest rate parity holds. Additionally, note that in assumption (v), the free-float volatility is $\sigma=10.28 \%$. Therefore, we can fairly assume that $\mathrm{S}$ follows a normal distribution with mean $\mu_{s}=$ 1.1019 and standard deviation $\sigma=10.28 \%$.

(vii) $K \sim N\left(\mu, \sigma_{K}^{2}\right.$ ). Similar to Section 5.2 (vii), the strike price follows a normal distribution with mean $\mu$ and standard deviation $\sigma_{K}$.

(viii) $\mu=1.0319$. From Table 6 , the average appreciation of the G10 and 10 managed-float carry trade Portfolio 5 is 3.19 percent against USD in periods of low sample volatility innovations. Therefore, the mean strike price is $\mu=1$ $+0.0319=1.0319$.

(ix) $\sigma_{K}=5 \%$. I choose this value arbitrarily to indicate that that most of the central bank's intervention occurs within an up and down 5 percent band of the mean strike price $\mu$. This value is different from that in Section $5.2\left(\sigma_{K}=10 \%\right)$. In Table 6, the managed-float investment currencies appreciate only 3.19 percent on average in periods of low sample volatility innovations, indicating a tighter range of currency intervention. Therefore, I use a smaller $\sigma_{K}$.

I also generate 1,000 hypothetical free-float exchanges rate $S$ randomly with a normal distribution, as in assumption (vi) and calculate the option value for each $S$. In the LSM simulation, I use 1,000 random normal strikes, 1,000 time-steps, and 6,000 time paths. For each $S$, I calculate the option price 6 times and take the median value as its option price. Then, I sort these 1,000 stochastic strike American call option prices from low to high and report the 5\%,50\%, and 95\% percentiles. I present the results in Table 8 . Note that in Table 6 , the absolute value of the average $\mathrm{H} / \mathrm{L}$ carry trade return difference between managed-float and free-float is $7.15 \%$ during periods of low sample volatility innovations. The difference in returns is close to the $50 \%$ percentile of the call option price.

I also calculate the put option value in this set up as a comparison. All parameters are the same as for the call option. Table 8 presents the results. The value of the put option is very small for $5 \%$ and $50 \%$, but may become valuable in extreme cases ( $95 \%$ percentile).

\subsection{Sensitivity analysis}

Table 9 presents the prices of the American put option with stochastic strikes for different parameters. Two parameters stay the same: the hypothetical free-float 
exchange rate is $S=0.7528$ and the US average interest rate is $r_{d}=1.680 \%$. Panel A reports the put option prices with different strike price volatilities $\sigma_{K}$ with a normal distribution. Panel B reports the put option prices with different means of the strike price $\mu$. Panel $\mathrm{C}$ reports the put option prices with different times to maturity $T$, from 1 month to 1 year. Panel D reports the put option prices with different local currency interest rates $r_{f}$. Panel E reports the put option prices with different free-float volatilities $\sigma$. The blanks indicate that the parameters stay the same.

As we can see from Table 9, the mean strike price, strike price volatility, and time to maturity have considerable effects on the price of the put option. This is intuitive. A higher intervention threshold, a wider spread in the intervention prices and a longer period to intervene will lead the central bank to spend more of its FX reserves. 
Table 9: Prices of American Currency Put Option with Stochastic Strikes for Different Parameters

\begin{tabular}{|c|c|c|c|c|c|c|c|}
\hline \multicolumn{8}{|c|}{ Prices of American Currency Put Option with Stochastic Strikes for Different Parameters } \\
\hline \multicolumn{8}{|c|}{ Panel A: Different $\sigma_{K}$} \\
\hline$S$ & $T$ & $r_{d}$ & $r_{f}$ & $\sigma$ & $\mu$ & $\sigma_{K}$ & Put Option Price \\
\hline \multirow[t]{4}{*}{0.7582} & 0.0833 & $1.680 \%$ & $7.717 \%$ & $13.24 \%$ & 0.8417 & $5 \%$ & $8.92 \%$ \\
\hline & & & & & & $10 \%$ & $9.90 \%$ \\
\hline & & & & & & $15 \%$ & $11.42 \%$ \\
\hline & & & & & & $20 \%$ & $13.13 \%$ \\
\hline \multicolumn{8}{|c|}{ Panel B: Different $\mu$} \\
\hline$S$ & $T$ & $r_{d}$ & $r_{f}$ & $\sigma$ & $\mu$ & $\sigma_{K}$ & Put Option Price \\
\hline \multirow[t]{4}{*}{0.7582} & 0.0833 & $1.680 \%$ & $7.717 \%$ & $13.24 \%$ & 0.9 & $10 \%$ & $14.92 \%$ \\
\hline & & & & & 0.8417 & & $9.90 \%$ \\
\hline & & & & & 0.8 & & $6.87 \%$ \\
\hline & & & & & 0.75 & & $3.93 \%$ \\
\hline \multicolumn{8}{|c|}{ Panel C: Different $T$} \\
\hline$S$ & $T$ & $r_{d}$ & $r_{f}$ & $\sigma$ & $\mu$ & $\sigma_{K}$ & Put Option Price \\
\hline 0.7582 & 0.0833 & $1.680 \%$ & $7.717 \%$ & $13.24 \%$ & 0.8417 & $10 \%$ & $9.90 \%$ \\
\hline \multicolumn{8}{|c|}{ Table 9 Continued } \\
\hline & 0.25 & & & & & & $10.64 \%$ \\
\hline & 0.5 & & & & & & $11.85 \%$ \\
\hline & 0.75 & & & & & & $12.85 \%$ \\
\hline & 1 & & & & & & $13.99 \%$ \\
\hline \multicolumn{8}{|c|}{ Panel D: Different $r_{f}$} \\
\hline$S$ & $T$ & $r_{d}$ & $r_{f}$ & $\sigma$ & $\mu$ & $\sigma_{K}$ & Put Option Price \\
\hline \multirow[t]{4}{*}{0.7582} & 0.0833 & $1.680 \%$ & $5 \%$ & $13.24 \%$ & 0.8417 & $10 \%$ & $9.70 \%$ \\
\hline & & & $7.717 \%$ & & & & $9.90 \%$ \\
\hline & & & $10 \%$ & & & & $10.04 \%$ \\
\hline & & & $15 \%$ & & & & $10.28 \%$ \\
\hline \multicolumn{8}{|c|}{ Panel E: Different $\sigma$} \\
\hline$S$ & $T$ & $r_{d}$ & $r_{f}$ & $\sigma$ & $\mu$ & $\sigma_{K}$ & Put Option Price \\
\hline \multirow[t]{5}{*}{0.7582} & 0.0833 & $1.680 \%$ & $7.717 \%$ & $5 \%$ & 0.8417 & $10 \%$ & $9.77 \%$ \\
\hline & & & & $10 \%$ & & & $9.85 \%$ \\
\hline & & & & $13.24 \%$ & & & $9.90 \%$ \\
\hline & & & & $15 \%$ & & & $9.98 \%$ \\
\hline & & & & $20 \%$ & & & $10.02 \%$ \\
\hline
\end{tabular}


Table 9 illustrates the prices of the American currency put option with stochastic strikes for different parameters. The hypothetical free-float exchange rate is $S=$ 0.7528 and the U.S. average interest rate is $r_{d}=1.680 \%$. The baseline values of parameters $T, r_{d}, r_{f}, \sigma, \mu$, and $\sigma_{K}$ follow the assumptions in Section 5.2. Panel A reports the put option prices with different strike price volatilities $\sigma_{K}$ with a normal distribution. Panel B reports the put option prices with different means of the strike price $\mu$. Panel $\mathrm{C}$ reports the put option prices with different times to maturity $T$ from 1 month to 1 year. Panel D reports the put option prices with different local currency interest rates $r_{f}$. Panel $\mathrm{E}$ reports the put option prices with different free-float volatilities $\sigma$. The blanks indicate that the parameters stay the same.

Similar to Table 9, Table 10 reports the prices of the American call option with stochastic strikes for different parameters. The hypothetical free-float exchange rate is $S=1.1019$ and the US average interest rate is $r_{d}=1.582 \%$. Panel A reports the call option prices with different strike price volatilities $\sigma_{K}$ with a normal distribution. Panel B reports the call option prices with different means of the strike price $\mu$. Panel $\mathrm{C}$ reports the call option prices with different times to maturity $T$, from 1 month to 1 year. Panel D reports the call option prices with different local currency interest rates $r_{f}$. Panel $\mathrm{E}$ reports the call option prices with different free-float volatilities $\sigma$. The blanks indicate that the parameters stay the same.

As we can see from Table 10, the mean strike price and strike price volatility have considerable effects on the price of the call option. This is intuitive. A lower intervention threshold and wider spread in the intervention prices lead the central bank to accumulate more FX reserves. Unlike in Table 9, however, the time to maturity does not affect the call option price very much. For the government, exchanging high interest rate local currency with USD foregoes the high yield of the local currency. In addition, in periods of low volatility innovations, the currency volatility itself is more likely acceptable for the government, which may choose to intervene or just let it be. Longer periods do not necessarily indicate that the government needs to intervene much more in the market. 
Table 10: Prices of American Currency Call Option with Stochastic Strikes for Different Parameters

\begin{tabular}{|c|c|c|c|c|c|c|c|}
\hline \multicolumn{8}{|c|}{ Prices of American Currency Call Option with Stochastic Strikes for Different Parameters } \\
\hline \multicolumn{8}{|c|}{ Panel A: Different $\sigma_{K}$} \\
\hline$S$ & $T$ & $r_{d}$ & $r_{f}$ & $\sigma$ & $\mu$ & $\sigma_{K}$ & Call Option Price \\
\hline \multirow[t]{4}{*}{1.1019} & 0.0833 & $1.582 \%$ & $7.759 \%$ & $10.28 \%$ & 1.0319 & $5 \%$ & $7.27 \%$ \\
\hline & & & & & & $10 \%$ & $8.55 \%$ \\
\hline & & & & & & $15 \%$ & $10.19 \%$ \\
\hline & & & & & & $20 \%$ & $12.03 \%$ \\
\hline \multicolumn{8}{|c|}{ Panel B: Different $\mu$} \\
\hline$S$ & $T$ & $r_{d}$ & $r_{f}$ & $\sigma$ & $\mu$ & $\sigma_{K}$ & $\begin{array}{l}\text { Call Option } \\
\text { Price }\end{array}$ \\
\hline \multirow[t]{5}{*}{1.1019} & 0.0833 & $1.582 \%$ & $7.759 \%$ & $10.28 \%$ & 1 & $5 \%$ & $10.28 \%$ \\
\hline & & & & & 1.0319 & & $7.27 \%$ \\
\hline & & & & & 1.05 & & $5.73 \%$ \\
\hline & & & & & 1.08 & & $3.50 \%$ \\
\hline & & & & & 1.1 & & $2.36 \%$ \\
\hline \multicolumn{8}{|c|}{ Panel C: Different $T$} \\
\hline$S$ & $T$ & $r_{d}$ & $r_{f}$ & $\sigma$ & $\mu$ & $\sigma_{K}$ & $\begin{array}{l}\text { Call Option } \\
\text { Price }\end{array}$ \\
\hline \multirow[t]{5}{*}{1.1019} & 0.0833 & $1.582 \%$ & $7.759 \%$ & $10.28 \%$ & 1.0319 & $5 \%$ & $7.27 \%$ \\
\hline & 0.25 & & & & & & $7.35 \%$ \\
\hline & 0.5 & & & & & & $7.49 \%$ \\
\hline & 0.75 & & & & & & $7.56 \%$ \\
\hline & 1 & & & & & & $7.67 \%$ \\
\hline \multicolumn{8}{|c|}{ Panel D: Different $r_{f}$} \\
\hline$S$ & $T$ & $r_{d}$ & $r_{f}$ & $\sigma$ & $\mu$ & $\sigma_{K}$ & $\begin{array}{l}\text { Call Option } \\
\text { Price }\end{array}$ \\
\hline \multirow[t]{3}{*}{1.1019} & 0.0833 & $1.582 \%$ & $5 \%$ & $10.28 \%$ & 1.0319 & $5 \%$ & $7.32 \%$ \\
\hline & & & $7.759 \%$ & & & & $7.27 \%$ \\
\hline & & & $10 \%$ & & & & $7.22 \%$ \\
\hline \multicolumn{8}{|c|}{ Table 10 Continued } \\
\hline & & & $15 \%$ & & & & $7.19 \%$ \\
\hline \multicolumn{8}{|c|}{ Panel E: Different $\sigma$} \\
\hline$S$ & $T$ & $r_{d}$ & $r_{f}$ & $\sigma$ & $\mu$ & $\sigma_{K}$ & $\begin{array}{l}\text { Call Option } \\
\text { Price }\end{array}$ \\
\hline \multirow[t]{5}{*}{1.1019} & 0.0833 & $1.582 \%$ & $7.759 \%$ & $2 \%$ & 1.0319 & $5 \%$ & $7.16 \%$ \\
\hline & & & & $5 \%$ & & & $7.22 \%$ \\
\hline & & & & $10.28 \%$ & & & $7.27 \%$ \\
\hline & & & & $15 \%$ & & & $7.42 \%$ \\
\hline & & & & $20 \%$ & & & $7.67 \%$ \\
\hline
\end{tabular}


Table 10 illustrates the prices of the American currency call option with stochastic strikes for different parameters. The hypothetical free-float exchange rate is $S=$ 1.1019 and the U.S. average interest rate is $r_{d}=1.582 \%$. The baseline values of parameters $T, r_{d}, r_{f}, \sigma, \mu$, and $\sigma_{K}$ follow the assumptions in Section 5.3. Panel A reports the option prices with different strike price volatilities $\sigma_{K}$ with a normal distribution. Panel B reports the option prices with different means of the strike price $\mu$. Panel $\mathrm{C}$ reports the option prices with different time to maturity $T$ from 1 month to 1 year. Panel D reports the option prices with different local currency interest rate $r_{f}$. Panel E reports the option prices with different free-float volatilities $\sigma$. The blanks indicate that the parameters stay the same.

\section{Policy Implications and Future Developments}

\subsection{Policy implications}

First, the option value in government currency intervention can be an indicator and measure of potential government currency intervention. The implication is simple. When the option value is low, the government is less likely to intervene in currency markets, so the amount of the intervention is low. However, when the option value is high, the government is more likely to intervene in currency markets currently or in the future, so the amount of intervention will be high. The time-varying nature of the option also indicates that its value changes as circumstances change, leading to an increase or decrease in government currency intervention.

Second, for a major economy (e.g. China), gradual reform to its currency regime is usually preferable over a sudden change. To make the transition from a fixedrate/managed-float to a free-float regime, the country needs to intervene less in the currency market over time. This is equivalent to making the option value in the government currency intervention less valuable over time. There are two ways to make the change: a sudden change or gradual reform.

A sudden change means that the country changes from fixed-rate/managed-float to a free-float regime in a very short period, such as a sudden announcement from the central bank. The sudden transition can happen intentionally or unintentionally by force during a currency crisis (e.g. Thailand in 1997 and Russia in 2014). For a small economy, a sudden change in the currency regime may succeed because it may not trigger global volatility or cause other contagious effects. However, the case for a major economy is different. Abruptly abandoning a currency intervention policy will likely trigger global volatility, change exchange rate expectations, and cause the local currency (which is usually an investment currency) to depreciate, therefore making the put option very valuable. It also imposes a "sovereign default" on the implied option values of the currency intervention policy and may have spiral effects that impose a great cost on the economy.

Gradual reform usually take place over years. A central bank can gradually lift bans on currency conversion and intervene less in the market over time. This is unlikely to trigger global volatility and will slowly decrease the option value of government currency intervention. It is a better option for a major economy that needs a smooth 
transition.

Third, the timing for a smooth transition of a major economy such as China from managed-float/fixed-rate to free-float is when its currency becomes a funding currency: the average put option value is worthless in periods of high volatility or volatility innovations.

It is clearer if we look at an interesting case: the option value in government currency intervention for a funding currency. The literature states that funding currencies such as the Japanese Yen and Swiss Franc depreciate in periods of low volatility or volatility innovations, but appreciate significantly in periods of high volatility or volatility innovations. Therefore, in periods of high volatility or volatility innovations, the call option in funding currency intervention is valuable, but put option is out of the money and worthless. The central banks of Japan and Switzerland recently printed local currencies and bought USD to prevent their currencies from rising too much. This policy is credible because a country can, in theory, print an unlimited amount of its own currency. Instead of facing the risk of running out of currency reserves, the country actually accumulates foreign reserves. In periods of low volatility, usually accompanied by a stable macro environment, the funding currency tends to depreciate, but both the call and put option prices are low because the free-float exchange rate volatility and the strike price volatility are low. In addition, the expected strike price is close to a free-float exchange rate. Therefore, when a currency becomes a funding currency, the put option value of government currency intervention is low, regardless of global volatility. The currency can smoothly transition to a free-floating regime.

\subsection{Revisiting China's currency reform in $\mathbf{2 0 1 5}$}

An interesting application of the option value of government currency intervention is to look at China's currency reform in 2015. On August 11, 2015, the People's Bank of China (PBoC) announced that it planned to improve the quotation of the central parity of RMB against USD, which linked the daily central parity quotes directly to the previous day's closing on the inter-bank market. This market-oriented reform caused a sharp and further decline in the RMB exchange rate against USD, hitting the $2 \%$ daily fluctuation limit from time to time. The $\mathrm{PBoC}$ had to spend large amount of its currency reserves to defend the RMB exchange rate. From July 31, 2015 to December 31, 2016, the RMB declined 13.4\% against USD and China's FX reserves also decreased by 640.8 billion USD, an amount representing $17.55 \%$ of its total reserves. ${ }^{3}$

China's currency reform significantly increased global market volatility and caused widespread reversal in carry trade activities, leading to further decline in investment currencies, including the RMB. However, investors knew that the PBoC would intervene to defend the $\mathrm{RMB}$ exchange rate since it still maintained the $2 \%$ daily range band. Therefore, facing the declining value of RMB, an optimal strategy was to exchange RMB for USD (or other reserve currencies) as early and as much as

${ }^{3}$ Data Source: State Administration of Foreign Exchange, People's Republic of China. 
possible before the $\mathrm{PBoC}$ ran out of FX reserves. Thus, the $\mathrm{PBoC}$ had to intervene a lot in the early period when the RMB had a high value and intervene less over time as it gradually ran out of FX reserves. This changed the strike price probability distribution of the put option value of government currency intervention. A declining probability distribution substituted for the normal distribution I assumed in the American currency put option model with stochastic strikes. This new declining probability distribution increased the put option value of China's currency intervention.

As a hypothetical example, and for simplicity, suppose that the exchange rate starts at 1 and government intervention takes place discreetly from 0.98 to 0.8 for every 0.02 decline in the exchange rate. The probability of the strike price declines linearly. Without loss of generality, one possible realization of the linearly declining probabilities are $0.1818,0.1636,0.1455,0.1273,0.1091,0.0909,0.0727,0.0545$, 0.0364 , and 0.0182 as the exchange rate decreases from 0.98 to 0.8 in increments of 0.02. This result indicates a large-scale currency intervention at first. Then, it gradually decreases due to the reduction in currency reserves.

The other assumptions are similar to those in Section 5.2:

(i) The initial standardized exchange rate of Portfolio 5 is 1.

(ii) $S=0.7582 . S$ is the hypothetical free-float exchange rate if the managed-float currencies became free-floating during periods of high G10 volatility innovations. For simplicity, I use the average free-float exchange rate in assumption (vi) of Section 5.2 as a substitute.

(iii) $T=1 / 12$. The option's time to maturity is one month.

(iv) $r_{d}=1.680 \%$. The US interest rate is the same as in assumption (iii) of Section 5.2.

(v) $r_{f}=7.717 \%$. The local interest rate is the same as in assumption (iv) of Section 5.2.

(vi) $\sigma=13.24 \%$. The free-float volatility is the same as in assumption (v) of Section 5.2.

(vii) The probability distribution of strike price $K$ is as follows: from 0.98 to 0.8 , for every 0.02 decline in the exchange rate, the corresponding probabilities are $0.1818,0.1636,0.1455,0.1273,0.1091,0.0909,0.0727,0.0545,0.0364$, and 0.0182 .

With these assumptions, the new price of the American currency put option with stochastic strikes is $16.54 \%$. This result is close to the $17.55 \%$ decline in China's FX reserves from July 31, 2015 to December 31, 2016, when the USD/CNY exchange rate finally stabilized. However, in Table 8, during periods of high G10 volatility innovations, the $50 \%$ percentile of the put option price is only $9.94 \%$ under the normal distribution. China's currency reform in August 2015 changed the probability distribution of strike prices and increased the put option value of currency intervention, indicating that China had to spend a lot more currency reserves to keep the RMB from declining too fast. 


\subsection{Future developments}

In this study, I mainly assume that the strike price follows a normal distribution. However, other distributions are possible in reality. Future studies should aim to detect the true strike price distributions. Researchers can also apply the model of the option value of government currency intervention to other emerging markets, especially those that are in the process of exchange rate reforms. Moreover, government currency intervention is usually accompanied by some sort of currency control. The effects of currency controls on currency intervention are left for future research.

\section{Conclusion}

This study examines the risk-return profile of carry trade. I find that in periods of high volatility innovations, the average carry trade returns for emerging markets are higher than that for a sample of all countries or developed economies. Furthermore, I divide the emerging markets into three sub-groups based on their exchange rate regimes and combine each sub-group with G10 currencies separately to form three types of carry trades: the free-float carry trade, the managed-float carry trade, and the fixed-rate carry trade. The empirical results show that in periods of high volatility innovations, the average $\mathrm{H} / \mathrm{L}$ returns on free-float carry trade are significantly negative, which are similar to the results for developed economies. However, the average $\mathrm{H} / \mathrm{L}$ returns on managed-float and fixed-rate carry trades are close to zero, much higher than that of free-float carry trade.

Government currency intervention in emerging markets can explain the return differences. I provide an indirect evidence by combining the monitoring lists in Macroeconomic and Foreign Exchange Policies of Major Trading Partners of the United States with G10 currencies and form the intervention carry trade, which, in periods of high volatility innovations, outperforms the free-float carry trade but remains insignificant compared to managed-float and fixed-rate carry trades.

In times of high volatility innovations, investment currencies tend to depreciate. Governments intervene in foreign exchange markets with their currency reserves to support the local currency, thereby slowing down the depreciation process. From the investors' perspective, they trade the currency at a price higher than they could if the currency were to free float. I propose that there is an option value in government currency intervention. During periods of high volatility innovations, the call option is worthless, but the put option is valuable. I also show that the option value of government currency intervention can be calculated by an American currency put option model with stochastic strikes. The $50 \%$ percentile of the option price is close to the average difference in returns between managed-float and freefloat carry trades during periods of high G10 volatility innovations.

I also propose and calculate the American currency call option model with stochastic strikes in periods of low volatility innovations when governments with managed-float exchange regimes intervene to keep the local currency from rising too much. The $50 \%$ percentile of the option value is also close to the average 
absolute difference in returns between managed-float and free-float carry trades. There are interesting policy implications. The option value of government currency intervention can be an indicator and measure of potential government currency intervention. For a major managed-float/fixed-rate economy, gradual exchange rate reform is more preferable than a swift change is. A major economy such as China should convert to free-floating when its currency becomes a funding currency. An American currency put option model with modified stochastic strikes shows that China's currency reform in August 2015 changed the probability distribution of the strike prices and increased the value of the put option of government currency intervention. China had to spend a lot more FX reserves to defend its currency. The true strike price distributions, other model applications in emerging markets and the effects of currency controls on currency intervention are left for future research.

ACKNOWLEDGEMENTS. I especially thank my doctoral advisors Xiaochuan Zhou, Haiying Zhao and Hao Zhou for their guidance and inspiration. I also thank Bing Han, Xiaoyan Zhang, Jianfeng $\mathrm{Yu}$, and Jiandong $\mathrm{Ju}$ at the University of Toronto and Tsinghua University for helpful comments and discussions. All errors are my own.

\section{References}

[1] O. Accominotti, J. Cen, D. Chambers, and I. Marsh, Currency Regimes and the Carry Trade, (2017).

[2] D. W. Andrews, Heteroskedasticity and Autocorrelation Consistent Covariance Matrix Estimation, Econometrica: Journal of the Econometric Society, (1991), 817 - 858.

[3] G. Bakshi, and G. Panayotov, Predictability of Currency Carry Trades and Asset Pricing Implications, Journal of Financial Economics, 110(1), (2013), 139 - 163.

[4] R. Bansal, and M. Dahlquist, The Forward Premium Puzzle: Different Tales From Developed and Emerging Economies, Journal of International Economics, 51(1), (2000), 115 - 144.

[5] BIS, Triennial central bank survey: Foreign exchange turnover in April 2016, Bank for International Settlements, 2016.

[6] M. K. Brunnermeier, S. Nagel, and L. H. Pedersen, Carry Trades and Currency Crashes, NBER Macroeconomics Annual, 23(1), (2008), 313 - 348.

[7] C. Burnside, The carry trade in industrialized and emerging markets, Central Banking, Analysis, and Economic Policies Book Series, 20, (2015), 245 - 280.

[8] C. Burnside, M. Eichenbaum, I. Kleshchelski, and S. Rebelo, Do Peso Problems Explain the Returns to the Carry Trade?, The Review of Financial Studies, 24(3), (2011), 853 - 891. 
[9] C. Burnside, M. Eichenbaum, and S. Rebelo, Carry Trade: The Gains of Diversification, Journal of the European Economic Association, 6(2-3), (2008), $581-588$.

[10] C. Burnside, B. Han, D. Hirshleifer, and T. Y. Wang, Investor overconfidence and the forward premium puzzle, The Review of Economic Studies, 78(2), (2011), 523 - 558.

[11] E. Cassino, and M. Lewis, Currency Intervention-The Profitability of Some Recent International Experiences, Reserve Bank of New Zealand, (2012).

[12] M. Chernov, J. Graveline, and I. Zviadadze, Crash Risk in Currency Returns, Journal of Financial and Quantitative Analysis, 53(1), (2018), 137 - 170.

[13] J. H. Cochrane, Asset Pricing, Princeton University Press, Princeton, NJ, 2005.

[14] P. Disyatat, and G. Galati, The Effectiveness of Foreign Exchange Intervention in Emerging Market Countries: Evidence From the Czech Koruna, Journal of International Money and Finance, 26(3), (2007), 383 - 402.

[15] E. F. Fama, Forward and Spot Exchange Rates, Journal of Monetary Economics, 14(3), (1984), 319 - 338.

[16] E. Farhi, S. P. Fraiberger, X. Gabaix, R. Ranciere, and A. Verdelhan, Crash Risk in Currency Markets, NBER Working Paper W15062, (2009).

[17] R. A. Fry-McKibbin, and S. Wanaguru, Currency Intervention: A Case Study of an Emerging Market, Journal of International Money and Finance, 37, (2013), 25 - 47.

[18] S. Gilmore, and F. Hayashi, Emerging Market Currency Excess Returns, American Economic Journal: Macroeconomics, 3(4), (2011), 85 - 111.

[19] L. P. Hansen, and R. J. Hodrick, Forward Exchange Rates as Optimal Predictors of Future Spot Rates: An Econometric Analysis, Journal of Political Economy, 88(5), (1980), 829 - 853.

[20] A. Heath, G. Galati, and P. McGuire, Evidence of Carry Trade Activity, BIS Quarterly Review, (2007).

[21] IMF, Annual Report on Exchange Arrangements and Exchange Restrictions 2009, International Monetary Fund, 2009.

[22] IMF, Annual Report on Exchange Arrangements and Exchange Restrictions 2010, International Monetary Fund, 2010.

[23] IMF, Annual Report on Exchange Arrangements and Exchange Restrictions 2011, International Monetary Fund, 2011.

[24] IMF, Annual Report on Exchange Arrangements and Exchange Restrictions 2012, International Monetary Fund, 2012.

[25] IMF, Annual Report on Exchange Arrangements and Exchange Restrictions 2013, International Monetary Fund, 2013.

[26] IMF, Annual Report on Exchange Arrangements and Exchange Restrictions 2014, International Monetary Fund, 2014.

[27] IMF, Annual Report on Exchange Arrangements and Exchange Restrictions 2015, International Monetary Fund, 2015.

[28] IMF, Annual Report on Exchange Arrangements and Exchange Restrictions 2016, International Monetary Fund, 2016a. 
[29] IMF, World Economic Outlook: Too Slow for Too Long, International Monetary Fund, $2016 \mathrm{~b}$.

[30] Ò. Jordà, and A. M. Taylor, The Carry Trade and Fundamentals: Nothing to Fear But FEER Itself, Journal of International Economics, 88(1), (2012), 74 90.

[31] J. W. Jurek, Crash-neutral Currency Carry Trades, Journal of Financial Economics, 113(3), (2014), 325 - 347.

[32] H. G. Keefe, and E. W. Rengifo, Currency Options as Central Bank Risk Management Tool, Fordham University Working Paper Series, (2014).

[33] M. J. I. C. Kriljenko, Foreign Exchange Intervention in Developing and Transition Economies: Results of a Survey, International Monetary Fund, 3(95), (2003).

[34] S. S. Lee, and M. Wang, The impact of jumps on carry trade returns, Journal of Financial Economics, 131(2), (2019), 433 - 455.

[35] J. M. Londono, and H. Zhou, Variance Risk Premiums and the Forward Premium Puzzle, Journal of Financial Economics, 124(2), (2017), 415 - 440.

[36] F. A. Longstaff, and E. S. Schwartz, Valuing American Options by Simulation: A Simple Least-Squares Approach, The Review of Financial Studies, 14(1), (2001), 113 - 147.

[37] H. Lustig, N. Roussanov, and A. Verdelhan, Common Risk Factors in Currency Markets, The Review of Financial Studies, 24(11), (2011), 3731 3777.

[38] H. Lustig, N. Roussanov, and A. Verdelhan, Countercyclical Currency Risk Premia, Journal of Financial Economics, 111(3), (2014), 527 - 553.

[39] H. Lustig, and A. Verdelhan, The Cross Section of Foreign Currency Risk Premia and Consumption Growth Risk, American Economic Review, 97(1), (2007), 89 - 117.

[40] M. O. Mandeng, Central Bank Foreign Exchange Market Intervention and Option Contract Specification: The Case of Colombia, IMF Working Paper, 3(135), (2003).

[41] M. Melvin, L. Menkhoff, and M. Schmeling, Exchange Rate Management in Emerging Markets: Intervention via an Electronic Limit Order Book, Journal of International Economics, 79(1), (2009), 54 - 63.

[42] L. Menkhoff, L. Sarno, M. Schmeling, and A. Schrimpf, Carry Trades and Global Foreign Exchange Volatility, The Journal of Finance, 67(2), (2012), $681-718$.

[43] C. J. Neely, The Practice of Central Bank Intervention: Looking Under the Hood, Federal Reserve Bank of St. Louis, (2000).

[44] M. Nozaki, Do Currency Fundamentals Matter for Currency Speculators?, IMF Working Paper, 10(39), (2010).

[45] A. Ranaldo, and P. Söderlind, Safe Haven Currencies, Review of Finance, 14(3), (2010), 385 - 407.

[46] L. Sarno, P. Schneider, and C. Wagner, Properties of Foreign Exchange Risk Premiums, Journal of Financial Economics, 105(2), (2012), 279 - 310. 
[47] L. Sarno, and M. P. Taylor, Official Intervention in the Foreign Exchange Market: Is It Effective and, If So, How Does It Work?, Journal of Economic Literature, 39(3), (2001), 839 - 868.

[48] J. Yu, A sentiment-based explanation of the forward premium puzzle, Journal of Monetary Economics, 60(4), (2013), 474 - 491. 


\section{Appendix}

\section{A. Hypothesis Test Results with MSCI Volatility}

Table A1: Simple Hypothesis Test Results with MSCI Volatility

\begin{tabular}{|c|c|c|c|c|c|c|c|}
\hline \multicolumn{8}{|c|}{$\begin{array}{c}\text { Simple Hypothesis Test } \\
\mathrm{H}_{0}: \text { The average } \mathrm{H} / \mathrm{L} \text { carry trade return during periods of high stock } \\
\text { volatility innovations }=0\end{array}$} \\
\hline & & \multicolumn{2}{|c|}{$\begin{array}{l}\text { G10 and } 8 \text { Free- } \\
\text { Float }\end{array}$} & \multicolumn{2}{|c|}{$\begin{array}{c}\text { G10 and } 10 \\
\text { Managed-Float }\end{array}$} & \multicolumn{2}{|c|}{$\begin{array}{l}\text { G10 and } 10 \text { Fixed- } \\
\text { Rate }\end{array}$} \\
\hline & & $\begin{array}{c}\text { High } 35 \\
\text { MSCI } \\
\Delta \text { VOL }\end{array}$ & $\begin{array}{l}\text { High } \\
\text { G11 } \\
\text { MSCI } \\
\Delta \text { VOL }\end{array}$ & $\begin{array}{c}\text { High } 35 \\
\text { MSCI } \\
\Delta \text { VOL }\end{array}$ & $\begin{array}{l}\text { High } \\
\text { G11 } \\
\text { MSCI } \\
\Delta \text { VOL }\end{array}$ & $\begin{array}{c}\text { High } 35 \\
\text { MSCI } \\
\Delta \text { VOL }\end{array}$ & $\begin{array}{l}\text { High } \\
\text { G11 } \\
\text { MSCI } \\
\Delta \text { VOL }\end{array}$ \\
\hline \multirow{3}{*}{$\begin{array}{l}\text { Top 1/4 } \\
\text { quintile }\end{array}$} & Mean & $-4.41 \%$ & $-6.22 \%$ & $1.20 \%$ & $0.65 \%$ & $1.72 \%$ & $0.12 \%$ \\
\hline & $\mathrm{t}$ & -0.694 & -1.031 & 0.338 & 0.183 & 0.420 & 0.029 \\
\hline & p-value & 0.491 & 0.308 & 0.737 & 0.855 & 0.676 & 0.977 \\
\hline \multirow{3}{*}{$\begin{array}{l}\text { Top 1/5 } \\
\text { quintile }\end{array}$} & Mean & $-7.27 \%$ & $-5.45 \%$ & $-1.30 \%$ & $-1.19 \%$ & $-0.65 \%$ & $-1.38 \%$ \\
\hline & $\mathrm{t}$ & -0.975 & -0.754 & -0.324 & -0.306 & -0.134 & -0.273 \\
\hline & p-value & 0.335 & 0.455 & 0.747 & 0.761 & 0.894 & 0.787 \\
\hline \multirow{3}{*}{$\begin{array}{l}\text { Top } 1 / 6 \\
\text { quintile }\end{array}$} & Mean & $-6.50 \%$ & $-5.96 \%$ & $-0.81 \%$ & $-3.11 \%$ & $-1.91 \%$ & $-2.78 \%$ \\
\hline & $\mathrm{t}$ & -0.758 & -0.690 & -0.184 & -0.730 & -0.336 & -0.485 \\
\hline & p-value & 0.454 & 0.495 & 0.855 & 0.471 & 0.739 & 0.631 \\
\hline \multicolumn{8}{|c|}{ Table A1 Continued } \\
\hline \multirow{3}{*}{$\begin{array}{l}\text { Top 1/7 } \\
\text { quintile }\end{array}$} & Mean & $-11.78 \%$ & $-3.53 \%$ & $-4.27 \%$ & $-3.10 \%$ & $-3.72 \%$ & $-2.81 \%$ \\
\hline & $\mathrm{t}$ & -1.245 & -0.352 & -0.919 & -0.619 & -0.578 & -0.420 \\
\hline & p-value & 0.223 & 0.728 & 0.366 & 0.541 & 0.568 & 0.678 \\
\hline \multirow{3}{*}{$\begin{array}{l}\text { Top } 1 / 8 \\
\text { quintile }\end{array}$} & Mean & $-13.75 \%$ & $-6.83 \%$ & $-6.69 \%$ & $-4.30 \%$ & $-5.81 \%$ & $-5.01 \%$ \\
\hline & $\mathrm{t}$ & -1.338 & -0.621 & -1.477 & -0.865 & -0.880 & -0.732 \\
\hline & p-value & 0.193 & 0.540 & 0.152 & 0.395 & 0.387 & 0.471 \\
\hline
\end{tabular}

This table reports the simple hypothesis test results of the mean returns on the H/L carry trade portfolio of G10 economies and 8 free-float emerging markets, G10 economies and 10 managed-float emerging markets, and G10 economies and 10 fixed-rate emerging markets carry trades during periods of high MSCI volatility innovations, as in Lustig et al. (2011). The null hypothesis is that the average $\mathrm{H} / \mathrm{L}$ carry trade return during periods of high 35 MSCI or G11 MSCI volatility innovations is zero. The G11 economies are the G10 economies plus the US. The data for $35 \mathrm{MSCI}$ country indexes in local currencies are from Reuters (Datatream). The 35 countries/economies are the US, China, Japan, the United Kingdom, India, Brazil, the Euro area, Indonesia, South Korea, South Africa, Turkey, Australia, 
Canada, Switzerland, Argentina, Malaysia, Mexico, Russia, Taiwan, Thailand, the Philippines, Singapore, Hong Kong, Chile, Colombia, Poland, Sweden, the Czech Republic, Denmark, Egypt, Hungary, New Zealand, Norway, Pakistan, and Israel. The rows "Top 1/4 quintile," "Top $1 / 5$ quintile," "Top 1/6 quintile," "Top 1/7 quintile," and "Top $1 / 8$ quintile" show, respectively, the mean of the highest $1 / 4$, $1 / 5,1 / 6,1 / 7$, and $1 / 8$ quintile of the $\mathrm{H} / \mathrm{L}$ carry trade portfolio returns on the freefloat, managed-float, and fixed-rate carry trade portfolios sorted separately by the 35 MSCI volatility innovations (High 35 MSCI $\Delta$ VOL) and by the G11 MSCI volatility innovations (High G11 MSCI $\Delta$ VOL). T statistics and P-values are also reported. The sample period is from March 2000 to February 2017. Monthly transaction cost adjusted returns are used. All returns are annualized. 